\title{
Industrial System Dynamics for Environmental Sustainability: A case study on the UK Medical Technology sector
}

Mukesh Kumar; Email: mk501@cam.ac.uk; Institute for Manufacturing, University of Cambridge, 17 Charles Babbage Road, Cambridge, CB3 0FS, UK

Dr Mukesh Kumar is a lecturer in Industrial Engineering and Operations Management, Institute for Manufacturing, University of Cambridge. His main research and practice interests are in the areas of sustainability, risk and resilience in emerging and developed industrial systems. He has developed risk management processes for global manufacturing investment decisions and supply networks. Before joining the University of Cambridge, his previous roles were in the financial sector as a senior analyst and corporate finance consultant. He holds a $\mathrm{PhD}$ from the University of Cambridge in the area of Manufacturing Investment Risk.

Jagjit Singh Srai; Email: jss46@ @am.ac.uk; Institute for Manufacturing, University of Cambridge, 17 Charles Babbage Road, Cambridge, CB3 OFS, UK

Dr Jagjit Singh Srai is Head of the Centre for International Manufacturing, Institute for Manufacturing, University of Cambridge. As a Senior Academic in the University, his research, supported by major national and international funding bodies, focuses on the analysis, design and operation of international production, supply and service networks. Previous roles have been in industry working as a Supply Chain Director of a multinational regional business, Technical Director of a national business and other senior management positions within front-line operations. Jag also advises leading multinationals, governments and international institutions including UNCTAD, UNIDO, WEF. Dr Srai also holds a first-class honours degree in Chemical Process Engineering from Aston University, a PhD in International Supply Networks from University of Cambridge, is a Chartered Engineer and a Fellow of the Institute of Chemical Engineers.

Yuto Minakata; Email: yuto.minakata@gmail.com; Institute for Manufacturing, University of Cambridge, 17 Charles Babbage Road, Cambridge, CB3 OFS, UK

Mr Yuto Minakata is a Junior Managers Program Trainee at Bosch Japan. He finished Master of Philosophy (MPhil) in Industrial Systems, Manufacture and Management, Industrial Engineering and Management from the University of Cambridge in 2014. 


\begin{abstract}
This paper investigates environmental sustainability dynamics of an industrial system through a case study on the UK Medical Technology sector. This paper builds on an industrial system framework involving institutions, specialist firms, value/supply chains and industrial actors. Environmental sustainability dynamics are explored through infrastructure and structure factors of industrial systems that are primarily developed from theoretical domains of manufacturing systems, production networks and supply chains. Research findings suggest that structural components influence the industry system more radically than the infrastructural components. Environmental sustainability dynamics depend on the size of industrial actors, types/characteristics of product and process, and availability of specialist (funding/technology) firms.
\end{abstract}

Keywords: 1) Sustainability in Operations and Logistics, (2) Healthcare Operations Management, (3) Supply Network Design

\title{
1 Introduction
}

Environmental sustainability has been described as one of the greatest challenges over the coming decades. In 2008, the UK government passed the 'Climate Change Act', requiring an $80 \%$ national reduction in greenhouse gas emissions by 2050 based on a 1990 baseline, supported by reductions of $34 \%$ by 2020 and $50 \%$ by 2025 . It is suggested that $30 \%$ or more of the GHG generated is due to the inefficiencies of industrial systems in developed countries (Evans, Bergendahl, Gregory, \& Ryan, 2009). This implies that there is a need to approach sustainability from a systems view in order to understand the environmental sustainability dynamics (Seuring \& Gold, 2013). These dynamics can be explained by understanding what influences a complex industrial system for environmental sustainability and how (Forrester, 1958). Therefore, this paper addresses the research question - How can an industrial system be influenced to develop environmental sustainable operations?

\section{Theoretical foundation}

\subsection{Industrial system}

Manufacturing systems have evolved from simple raw material transformation in a factory to a highly complicated industrial system that "Include(s) the context, resources, activities, processes, actors, and interdependencies that support the creation and delivery of products and services"(Kumar \& Gregory, 2013; RAC, 2012). Today, the actors involved in manufacturing not only include the global industrial actors, but other external stakeholders. Theoretical work on clusters, business ecosystems and industry 
structure have highlighted the importance of institutions (e.g. through research, policy/regulation, knowledge transfer) and specialists (e.g. through funding, specialist equipment, technical support and services) that support an industry (Kumar, Srai, Pattinson, \& Gregory, 2013; Luo, Whitney, Baldwin, \& Magee, 2011; Porter, 1998; Srai, 2010; Srai, Christodoulou, \& Harrington, 2014). This research draws on industrial system frameworks with multiple subsystems/levels including institutions and specialists, Industrial Value/Supply Chain (VC/SC), core process/products and industrial actors (Figure 1).

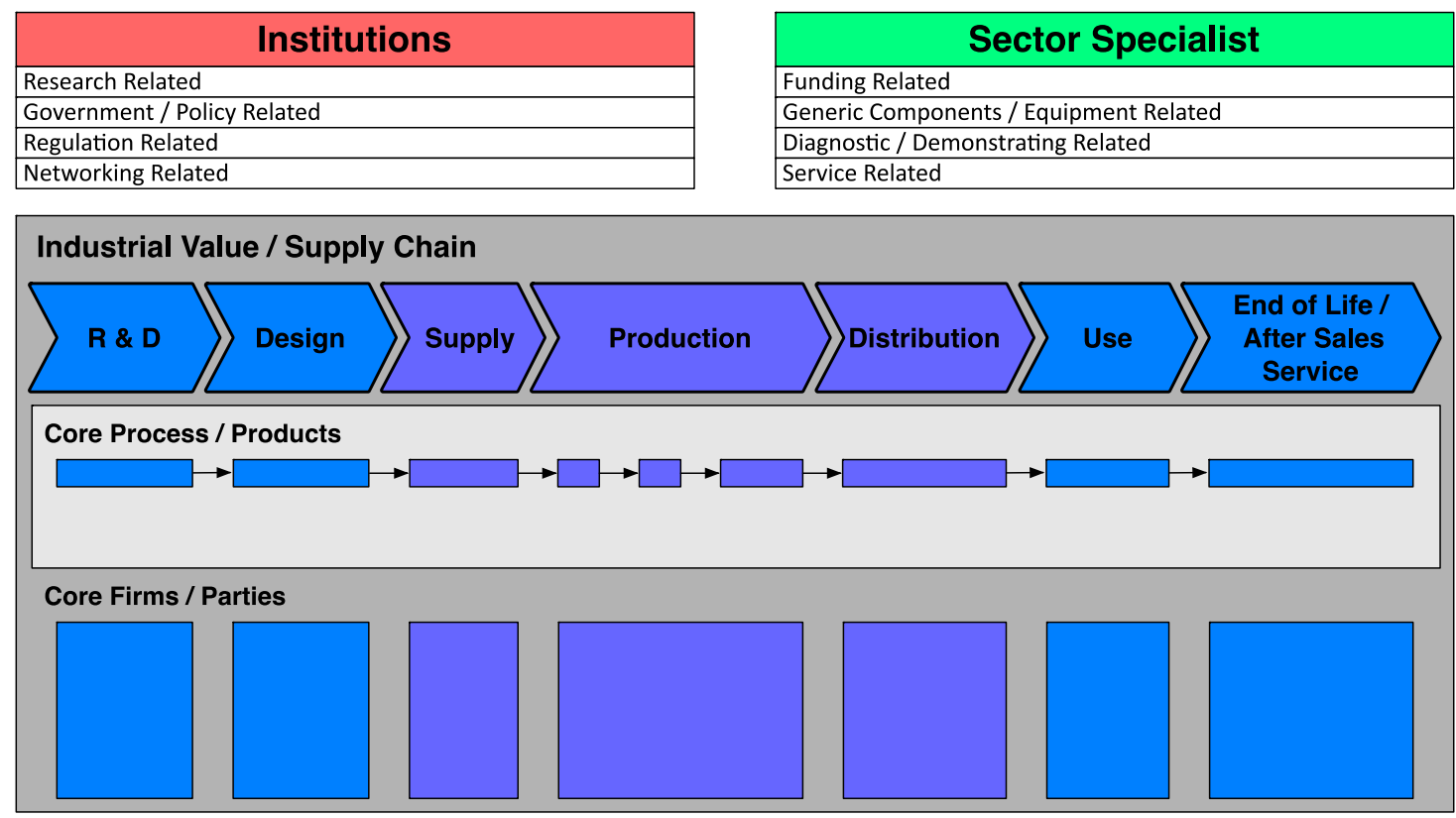

Figure 1: Industrial System Framework developed from (Kumar et al., 2013; Srai 2010; Srai et al., 2014)

\subsection{Dynamics or influences in Industrial systems}

Skinner was one of the earliest pioneers to look more closely at manufacturing involving a pattern of individual decisions and their influences to meet long term company objectives (Skinner, 1969). This view was expanded by Hayes and Wheelwright to observe manufacturing from a factory system perspective by considering the structural (capacity, facilities, technology, vertical integration) and infrastructural (workforce, quality, planning/control, organisational structure) elements (Hayes \& Wheelwright, 1984). Generally, these two types of elements are interdependent but have different characteristics. Theoretically, changes in any or all of the structural and infrastructural elements reconfigure or transform a system. The structure has a more radical and architectural influence on the system, whereas the infrastructure determines daily operations as well as accumulative improvements (Shi \& Gregory, 1998). Therefore, if we can develop the infrastructural and structural elements of an industrial system then we can observe dynamics - environmental dynamics, specifically in this research. 
During the late 1990's, further emphasis on the geographical location and coordination of factories was cited by Shi \& Gregory, leading to the international manufacturing perspective (Shi \& Gregory, 1998). In 1999, the importance of globalisation in cooperative and inter-organisational supplier relations was highlighted, leading to the theory of a supply chain as a system (Harland, Lamming, \& Cousins, 1999). Today, the actors involved in manufacturing not only include the global industrial actors, but other external stakeholders as well. Literature on clusters, business ecosystems and industry structure have highlighted the importance of institutions (e.g. through research, policy/regulation, knowledge transfer) and specialists (e.g. through funding, specialist equipment, technical support and services) that support an industry (Porter, 1998; Brusoni et al., 2009; Whitney et al., 2011). Additionally, an industrial system perspective extends supply chain to value chain, including upstream (R\&D and design) and downstream (market use and end of life/after sales service) to capture the entire range of industrial activities necessary for the provision of goods and services (Sturgeon, 2001). Although the end of life process such as waste management has a different nature to that of other industrial systems, it is an integral part of any manufacturing system and its importance is emphasised (Ellen Macarthur Foundation, 2013).

Building on the evolving nature of structure and infrastructure components discussed by authors such as Hayes \& Wheelwright and Shi \& Gregory, a new set of constructs for an industrial system is proposed, shown in table $1 \& 2$. It is important to note that companies traditionally take decisions influencing the structure and infrastructure of manufacturing systems. Whereas in an industrial system, a mixture of external stakeholders and industrial actors make these decisions.

Table 1 Evolution of Structural/Infrastructural Constructs of a System

\begin{tabular}{|c|c|c|}
\hline System Types & Structure (Architecture) & Infrastructure (Mechanism) \\
\hline $\begin{array}{l}\text { Factory } \\
\text { (Hayes \& Wheelwright, 1984) }\end{array}$ & $\begin{array}{ll}- & \text { Capacity } \\
\text { - } & \text { Facilities } \\
\text { - } & \text { Technology } \\
\text { - } & \text { Vertical integration }\end{array}$ & $\begin{array}{ll}\text { - } & \text { Workforce } \\
\text { - } & \text { Quality } \\
\text { - } & \text { Planning / control } \\
\text { - } & \text { Organisational structure }\end{array}$ \\
\hline $\begin{array}{l}\text { International Manufacturing } \\
\text { (Shi \& Gregory, 1998) }\end{array}$ & $\begin{array}{ll}\text { - } & \text { Factory's characteristics } \\
\text { - } & \text { (above) } \\
\text { - } & \text { Heographic dispersion } \\
\text { - } & \text { Vertical coordination }\end{array}$ & $\begin{array}{ll}\text { - } & \text { Dynamic response mechanism } \\
\text { - } & \text { Learning / knowledge transfer } \\
\text { - } & \text { Operational mechanism } \\
\text { - } & \text { / network evolution }\end{array}$ \\
\hline $\begin{array}{l}\text { Supply Chain } \\
\text { (Harland et al., 1999) }\end{array}$ & $\begin{array}{ll}\text { - } & \text { Capacity } \\
\text { - } & \text { Role configuration } \\
\text { - } & \text { Facility configuration } \\
\text { - } & \text { Make or buy }\end{array}$ & $\begin{array}{ll}\text { - } & \text { SC HR policy } \\
\text { - } & \text { Supplier Quality } \\
\text { - } & \text { Planning / control } \\
\text { - } & \text { Organisation structure } \\
\text { - } & \text { New product development } \\
\text { - } & \text { Performance measurement }\end{array}$ \\
\hline $\begin{array}{l}\text { Industrial System } \\
\text { (Porter, 1998; Sturgeon, 2001; }\end{array}$ & $\begin{array}{l}\text { - Product/service } \\
\text { characteristics }\end{array}$ & $\begin{array}{ll}\text { - } & \text { Industrial Actors } \\
\text { - } & \text { Product/Service Quality }\end{array}$ \\
\hline
\end{tabular}


Moore, 2005; Jacobides et al., 2006; Porter, 2007; Brusoni et al., 2009; Evans et al., 2009; Whitney et al., 2011; The Royal Academy of Engineering, 2012; Srai \& Christodoulou, 2014)
- $\quad \mathrm{VC} / \mathrm{SC}$ processes

- Capacity (including R\&D, Production, import/export etc.)

- Roles and relationship between institutions, specialists, VC/SC and industrial actors

- Technology

Table 2 Description of Proposed Industrial System Structure/Infrastructure

\begin{tabular}{ll}
\hline Name & Description \\
\hline Product/service characteristics & $\begin{array}{l}\text { Technology basis, number of components, materials used, } \\
\text { overall value, purpose etc. }\end{array}$ \\
\hline Value/supply chain (VC/SC) processes & $\begin{array}{l}\text { R\&D, design, supply chain development, production, } \\
\text { distribution, market, end of life/after sales service }\end{array}$ \\
\hline Capacity & $\begin{array}{l}\text { Total volume that an industrial system can have in its } \\
\text { VC/SC processes, including imports/exports }\end{array}$ \\
\hline Roles and relationship & Role of a certain actor type and its relationship within the \\
& industrial system (nature of behaviour with others) \\
\hline Technology & Technology that determines how a product/service can be \\
& produced and communicated with various actors \\
\hline Industrial actors & Actors involved at the various part of the VC/SC \\
\hdashline Product/service quality & Overall quality of the service offered (e.g. minimum \\
& requirement generally set by regulators) \\
\hline New product/process development & New product, VC/SC process, strategies, policies, etc. \\
\hdashline Institutions/specialists involvement & External stakeholders that have an influence on an \\
& industrial system (e.g. government, funding, regulatory \\
& bodies) \\
\hline
\end{tabular}

\subsection{Environment sustainability}

Source: Developed from Table 1

Environmental sustainability has been described as one of the greatest challenges over the coming decades. It is suggested industrial systems are responsible for $30 \%$ or more of Green House Gas (GHG) generated in industrial countries (Evans et al., 2009). Literature has emphasised the importance of systems thinking when considering sustainability. This implies that there is a need to approach sustainability from a systems view in order to understand the dynamics and implications of different environmental activities (Anarow et al., 2003; Evans et al., 2009; Seuring \& Gold, 2013). Various authors have proposed that in order to achieve industrial sustainability, activities targeted at multiple levels or sub-systems are necessary (Chertow, 2000; Fiksel, 2003; Braungart et al., 2007; Marchi et al., 2013). Following this view, fragmented literature on environmental activities were reviewed and categorised into three levels defined in the industrial system analytical framework:

- Institution/Specialist: Activities focused on influencing the overall industrial system

- Value/Supply Chain (VC/SC): Activities focused on influencing at inter-firm level 
- Industrial Actor: Activities focused on influencing in-house products/processes

\subsubsection{Institution/Specialist Level Environmental Activities}

Environmental Sustainability Concepts: Industrial ecology is one of the most commonly referred environmental sustainability concepts. The study is based on simulating a biological ecosystem by shifting an industrial process from a linear (open-loop) system to a circular (closed-loop) system to reuse waste (Frosch \& Gallopoulos, 1989; Garner, 1995). Models based on this concept can have either a focus on the product and its material flow or in defined geographical locations (Boons \& Baas, 1997). Cradle-tocradle $(\mathrm{C} 2 \mathrm{C})$ is one of the most proactive frameworks focusing on the product side. It aims to maintain or even upgrade resource quality and productivity through many cycles of use by having different processes for the 'biological nutrients' and 'technical nutrients'. Biological nutrients can be decomposed and allowed to re-enter the natural system, while technical nutrients should be kept within the system and used multiple times. (Braungart \& McDonough, 2002; Braungart et al., 2007). Industrial symbiosis or eco-industrial park is a model focused on the geographical location that involves two or more industrial facilities in relative geographic proximity that share energy, materials, or information (Chertow, 2000; Martin \& Eklund, 2011).

The concept of zero waste/emission is to maximise recycling, minimise waste/emission, reduce consumption and ensure that products are planned to be recovered internally or externally (Glavič \& Lukman, 2007). The ultimate goal is to produce no waste in air, water and land (Gravitis et al., 2004). In contrast to C2C, the approach is rather reactive in that it seeks to reduce the unintended negative consequences of processes of production and consumption (Braungart et al., 2007).

Environmental Policy/Strategy: Most environmental ministries in the industrialised countries were set up during the early 1970's (Martin, 1992). Since then, there has been a gradual development of the environmental policies that are in line with a certain sustainability concept. For example in 1973, Ministry of International Trade and Industry in Japan officially recommended a new policy to be developed on the basis of industrial ecology principles. This led to a strategy that aimed to reduce dependency on material resources through technology advancement (Erkman, 1997). Both national and international policies used to focus primarily on how to make production more environmental, rather than on consumption. This imbalance has been readdressed and now there is a greater emphasis on sustainable consumption, defined as:

"The use of goods and services that respond to basic needs and bring a better quality of life while minimising the use of natural resources, toxic materials and emission of waste and pollutants over the life cycle, so as not to jeopardise the need of future generations" (Southerton et al., 2004; Seyfang, 2006). 
Environmental Legalisation / Schemes: Environmental legalisation is a set of legal principles, acts, regulations, directives, and laws aimed to implement environmental policies (Glavič \& Lukman, 2007). For example, the European Union (EU) Registration, Evaluation, Authorisation and Restriction of Chemicals (REACH) regulation restricts the use of certain chemicals in various industries within its member states. There is also an indirect impact on domestic environmental law in many other countries (e.g. USA) since the modern supply chain is highly global (DG ENTR, 2007; Yang \& Percival, 2009). Another role of environmental regulation is to force or facilitate the adoption of environmental innovation, however there is a significant barrier in doing so (Murphy \& Gouldson, 2000).

Another method of influencing the industry as a whole is through voluntary schemes. ISO 14001 is one of the most commonly used standards from the International Organization of Standardization (ISO) regarding Environmental Management System (EMS) to support sustainable development. Nearly 8000 organisations in 72 countries had been certified by 1998 (Rondinelli \& Vastag, 2000). One of the main concerns regarding standards is its lack of legitimacy. Companies may be using standards merely as an image-building or public relations effort. With ISO 14001, it is difficult to influence the industry at a system level as the certification is facility specific and it does not have an influence amongst the facility's suppliers for example (Kleindorfer et al., 2005; Mueller et al., 2009).

\subsubsection{Value/Supply Chain Level Environmental Activities}

Green Value/Supply Chain Management: In this system level, much of the literature focuses on green supply chain management (GSCM). It is important to note that many authors refer to the extended supply chain (e.g. includes product design and end-of-life management) when discussing sustainability in this area. This is mainly due to the focus on adopting sustainability models such as $\mathrm{C} 2 \mathrm{C}$ or closed-loop systems (Kleindorfer et al., 2005; Srivastava, 2007). GSCM must be viewed as managing environmental activities of two or more transacting organisations. An organisation can either choose to get directly involved with its supply chain members (e.g. investing own resources) or use existing frameworks/market mechanisms to influence them (e.g. ISO 14001 as a supplier evaluation criteria for procurement) (Vachon \& Klassen, 2006).

From the influence of environmental sustainability concepts such as closed-loop aspect of industrial ecology, there is a great emphasis on the downstream operations (e.g. reverse logistics, waste management) within GSCM literature. Aspects of reverse logistics include: collecting, inspection/sorting, pre-processing, location and distribution as well as network design (Srivastava, 2007). In comparison to the traditional supply chain management, it requires more coordination with immediate 
customers/end-consumers along with greater interaction with suppliers (Vachon \& Klassen, 2006).

Environmental Collaboration: Collaborative mechanisms are becoming more important for industrial organisations from schemes such as extended producer responsibility. Legislation such as Waste Electronics and Electrical Equipment (WEEE) from the EU requires manufacturers to ensure the safe handling of their product's materials after the customer use phase. Generally, the producer links the different actors involved in the product's life cycle through coordinated collaboration as well as with other product manufacturers (Gottberg et al., 2006; Braungart et al., 2007).

Other examples of collaborative mechanisms include knowledge sharing activities regarding greener product design, process modification and reducing waste in the logistics process (Vachon \& Klassen, 2006). Marchi et al. (2013) has also discussed the importance for original equipment manufacturers (OEMs) to collaborate with their suppliers as well as key institutions and specialists (e.g. universities and service firms) to create and share new environmental knowledge on green product or processes.

\subsubsection{Industrial Actor Level Environmental Activities}

Eco Design : Eco design is a product development process that takes account of the total life cycle stages in order to minimise environmental impact through design (Srivastava, 2007). There are various aspects that are involved ranging from different product recovery methods, dematerialisation and alterative material/chemistry, shown in table 3. In the case of consumer electronics, the ease of disassembling a product at the end of life is a key concept for the manufacture due to the extended producer responsibility from the WEEE legislation (Platcheck et al., 2008). The product design phase can account up to $80 \%$ of the environmental sustainability factors, highlighting the importance of eco design (Maxwell \& van der Vorst, 2003).

Product Recovery: Product recovery refers to the range of activities aimed to reclaim value from a product at the end of its life cycle (Srivastava, 2007). It is an important aspect of industrial ecology or other industrial level environmental activities. Recycling is one of the most commonly used forms of recovery methods. It is defined as the resource recovery method through collection and treatment of waste products to be used as raw material in the manufacture of the same or a similar product (Glavič \& Lukman, 2007). Within recycling, it is important to distinguish between upcycling and downcycling. The former involves the upgrading of waste materials into more valuable products, contributing to the idea of C2C (Braungart et al., 2007; Pol, 2010). The latter implies a downgrade in material quality, limiting usability and it is part of cradle-tograve (open-loop system) in contrast to C2C (Braungart et al., 2007). 
Green Production: There are different forms of environmental production methods within literature. One of the more proactive approaches is cleaner production. Compared to the rather reactive end-of-pipe practices, this method encompasses dematerialisation and pollution prevention at the source, rather than waste minimisation and pollution control at the end of process (Glavič \& Lukman, 2007; Wang \& Côté, 2011). Examples of cleaner production technologies include using environmentally friendly materials (e.g. replacing organic solvents by water) and modification of the combustion chamber design (Frondel et al., 2007). In any green production methods, the use of efficiency techniques (e.g. lean, total quality management) as well as the use of by-products (e.g. waste heat) are commonly found (Kleindorfer et al., 2005; Linton et al., 2007).

Green Corporate Policy/Strategy: General corporate policies can be divided into ecoeffective or eco-efficiency oriented ones. Eco-effective policies are the backbone of $\mathrm{C} 2 \mathrm{C}$ or industrial ecology concepts that aims to enable upcycling, which is not only the redirection of material flow, but also the establishment of new forms of supportive information and finance flow networks (Braungart et al., 2007). In contrast, ecoefficiency oriented policies relates to downcycling, creating less waste and pollution, therefore supporting environmental concepts such as zero waste/emission (Orsato, 2006; Wang \& Côté, 2011).

Within strategies, companies can engage environmental sustainability in a proactive manner (e.g. beyond compliance/environmental leadership strategy) or in a reactive one (e.g. environmentally neutral/responsive strategy) (Orsato, 2006; Baines et al., 2012; Marchi et al., 2013). There are also new types of strategies emerging. One example is the product service system (PSS) strategy based on dematerialisation principle by leasing products (e.g. 'power-by-the hour' strategy by Rolls Royce) rather than selling them. It is noted that collaboration with customers and suppliers as well as the supporting structure/infrastructure is an important aspect for an effective PSS strategy (Tsoulfas \& Pappis, 2006; Baines et al., 2007). Others include compliance with regulations due to influences of institutional level environmental activities and renewable energy sourcing through industrial incentives (Jacobsson \& Lauber, 2006; Tsoulfas \& Pappis, 2006).

In support of the corporate policies and strategies, organisations often use tools such as energy, resource, waste and carbon (ERWC) framework and life cycle assessment (LCA) for environmental accounting purposes. ERWC framework is based on measuring the factory level environmental impact via carbon footprint, considering energy efficiency, resource utilisation and waste minimisation (Tridech \& Cheng, 2010). LCA considers total environmental impact of the used materials, energy inputs, wastes, and emissions from the production of the first raw material to the final disposition of the manufactured product (Joshi, 2000). 
Environmental activities in the above three levels gathered from literature are shown in table 3. Some of these activities are repeated in multiple systems due to its relevance in more than one level. It is important to mention that these activities have different perspectives. VC/SC level has a higher focus on the activities requiring collaboration with multiple actors, whereas industrial actor level is primary in-house activities. For example, green/eco design can be done through both collaborations or individually. 


\begin{tabular}{|c|c|c|c|}
\hline \multicolumn{2}{|l|}{ Institution/ Specialist Level } & \multicolumn{2}{|c|}{ Industrial Actor Level } \\
\hline Environmental Sustainability Concepts & Source No. & Eco Design & Source No. \\
\hline Industrial ecology & $1,2,6,10,27$ & Design for material and product recovery & $5,13,14$ \\
\hline - industrial ecosystem & $1,, 10,12$ & Design for disassembly & $14,15,18$ \\
\hline - industrial symbiosis/ Eco-industrial park & $1,26,27,28$ & Design for waste minimization & 1,19 \\
\hline - Circular economy & 38,39 & Design for remanufacturing & $1,5,14$ \\
\hline - Cradle to cradle & $1,11,12$ & Design for recycling issues & $1,5,14$ \\
\hline Zero waste/ zero emission & $1,12,40$ & Design for dematerialisation & 1,21 \\
\hline Environmental Policy/ Strategy & Source No. & Design for reuse / modularity & 17,20 \\
\hline Environmental Policy & $49,59,51,52$ & Design for product life extension & 19,29 \\
\hline - Sustainable production/green operation & 1,6 & Design under legislation and regulation & 16,19 \\
\hline - Sustainable consumption & $1,46,53$ & Packaging design & 17,22 \\
\hline Industrial pollution prevention strategy & 2,6 & Better choices of material & $23,24,35$ \\
\hline Product service system strategy & see right & Green chemistry & $1,2,6$ \\
\hline Life cycle assessment & see right & Product Recovery & Source No. \\
\hline Renewable energy sourcing & see right & Recycling & $1,6,29$ \\
\hline Environmental Legalisation/Schemes & Source No. & - upcycling & 25,26 \\
\hline Environmental regulation & $16,19,47,50$ & - downcycling & 12,27 \\
\hline Environmental Standards & 8,41 & Reuse & $1,6,29$ \\
\hline - ISO 14001 & $1,2,8,41,45,48$ & Repair & $1,6,29$ \\
\hline - Eco-management and auditing scheme (EMAS) & $1,42,43,45$ & Regeneration & 1,28 \\
\hline - Responsible care & 1,45 & Refurbish & 6,7 \\
\hline Voluntary environmental & 1,42 & Remanufacturing & $1,5,6,29$ \\
\hline \multicolumn{2}{|l|}{ Value/ Supply Chain Level } & Dis-assembly & 6,29 \\
\hline Green value/Supply Chain Management & Source No. & Green Production & Source No. \\
\hline Green design & see right & Cleaner production & $1,5,10,31$ \\
\hline Green procurement & 9,37 & End of pipe practise & $1,31,32$ \\
\hline
\end{tabular}




\begin{tabular}{|l|l|l|l|} 
Green manufacturing (inc. product recovery) & see right & Pollution prevention & 1,32 \\
\hline Green logistics & $6,9,16,17$ & Waste minimization & 1,6 \\
\hline Green network & $6,9,12,16$ & Quality / lean/ TQM / IIT techniques & 5,8 \\
\hline Green waste management & 6,17 & Use of by-product (e.g. waste heat) & 5,8 \\
\hline Green strategy & $1,2,4,5,6,9$ & Green Corporate Policy / Strategy & Source No. \\
\hline Product life extension & 5,17 & Eco-efficiency & $1,4,12,11,12$ \\
\hline Life cycle assessment & see right & Eco-effectiveness & $10,11,12$ \\
\hline Environmental Collaboration & Source No. & Environmentally neutral / responsive strategy & 30 \\
\hline Extended producer responsibility & 12,19 & Beyond compliance / environmental leadership strategy & $4,8,30,33$ \\
\hline Intelligent material pooling & 12 & Eco branding strategy & 4,33 \\
\hline Shared risk and benefits/ knowledge sharing & 9,33 & Environmental cost leadership strategy & 4,33 \\
\hline & & Selection of pollution prevention strategies & $1,2,6,9$ \\
\hline & & Product service system strategy & $1,5,17,54$ \\
\hline & & $\begin{array}{l}\text { Implementation of environmental management system / } \\
\text { regulatory compliance }\end{array}$ & $1,2,8,9,17$ \\
\hline & & Renewable energy sourcing & 34,36 \\
\hline & & Environmental accounting & 1,17 \\
\hline & - Life cycle assessment & $1,2,3,5$ \\
\hline & & ERW framework & 55,56 \\
\hline & Application of quality / lean / TQM / JIT principle & $5,8,9$ \\
\hline
\end{tabular}

Table 3: Environmental sustainability activities (Refer sources in appendix 1) 


\section{Approach}

Due to the focus on the emerging phenomena of understanding environmental dynamics within an industrial system, a case study methodology is selected. As the focus of this research is on environmental sustainability dynamics within an industrial system, various complex relations are investigated between external stakeholders, processes and industrial actors. The primary focus of this research is on the industrial system characteristics and its dynamics with environmental sustainability. Therefore multiple case studies are chosen to analyse different sector segments to draw on its characteristics. Yin (1994) also states that the unit of analysis can be either: holistic focus on the totality; or embedded - focus on specific units or processes. This study will use embedded multiple case studies since the interested units are the UKMTS industrial system characteristics and its environmental activities in order to evaluate the dynamics between the two.

In order to choose the industry to apply the framework developed in Literature Review, selection criteria were developed, shown in Table 4. From the major UK industries, three industries were chosen according to the complexity of the industrial system structure and infrastructure. By applying the developed framework to such a complex industry, it is possible to fully assess the capability of this new approach. Adding to the complexity, UK Life Science is highly regulated with growing regulatory pressure (Cairns, 2014). From the three listed, Life Science industry was chosen due to its complexity and the low focus on environmental sustainability. From this low maturity, it has a potential to observe a significant influence of environmental sustainability on the current system.

Table 4 Industry Selection Criteria

\begin{tabular}{lllll}
\hline Industry & Country & Structure & Infrastructure & $\begin{array}{l}\text { Regulation / } \\
\text { Env. Sustainability }\end{array}$ \\
\hline Life Science & UK & Complex & Complex & $\begin{array}{l}\text { Highly regulated / } \\
\text { Low focus }\end{array}$ \\
\hline Automotive & UK & Complex & Complex & $\begin{array}{l}\text { Relatively less / } \\
\text { High focus }\end{array}$ \\
\hline Food & UK & Complex & Complex & $\begin{array}{l}\text { Least regulated / } \\
\text { High focus }\end{array}$ \\
\hline
\end{tabular}

Two product-based industrial systems in two different segments are investigated. These were chosen as; In Vitro Diagnostic (IVD) - tests conducted from samples derived from the human body such as blood and urine, and Single Use Instrument (SUI) - devices that are intended to be used on an individual patient during a single procedure and then discarded. These segments were chosen due to their significance in terms of annual turnover and employment. Selected products for the case studies are shown in Table 5. Addendum B shows further detail on the overview of UKMTS including detailed product descriptions. 
Table 5 Selection of Products

\begin{tabular}{lll}
\hline Product & Segment & Note \\
\hline PCR* system & IVD & $\begin{array}{l}\text { Used for professional diagnostics (e.g. infectious } \\
\text { disease) }\end{array}$ \\
\hline SMBG** system & IVD & Used to self monitor glucose level for diabetes \\
\hline Single use syringe & SUI & Used to inject substances or take samples \\
\hline Single use forceps & SUI & Used for various surgeries \\
\hline${ }^{*} P C R:$ Polymerised Chain Reaction, ${ }^{* * S M B G: ~ S e l f-M o n i t o r i n g ~ B l o o d ~ G l u c o s e ~}$
\end{tabular}

The case study approach involved mapping the industrial system from secondary data and then validating these maps with primary data. Four product based industrial systems are mapped. The primary data are collected based on interviews. The format of the interview was semi-structured rather than structured due to the nature of this study requiring interviews from various actors. Key stakeholders to interview were chosen from the institutions, specialists and industrial actors identified from the initial industrial system map development process. On average, $45 \mathrm{~min}$ interviews were conducted with a total of 19 interviewees. The positions of the interviewees ranged from high level (e.g. managing director, head of department) to general managers (e.g. $\mathrm{R} \& \mathrm{D}$, quality, regulatory). Data analysis was structured around key concepts derived from the literature. With-in-case analysis and cross case analysis was performed to identify key evidence of environmental sustainability influences and within an industrial system, along with pattern matching for environmental sustainability influences which helped to link the data with the key findings (Figure 2 and3; Table 6, 7, 8 and 9). 


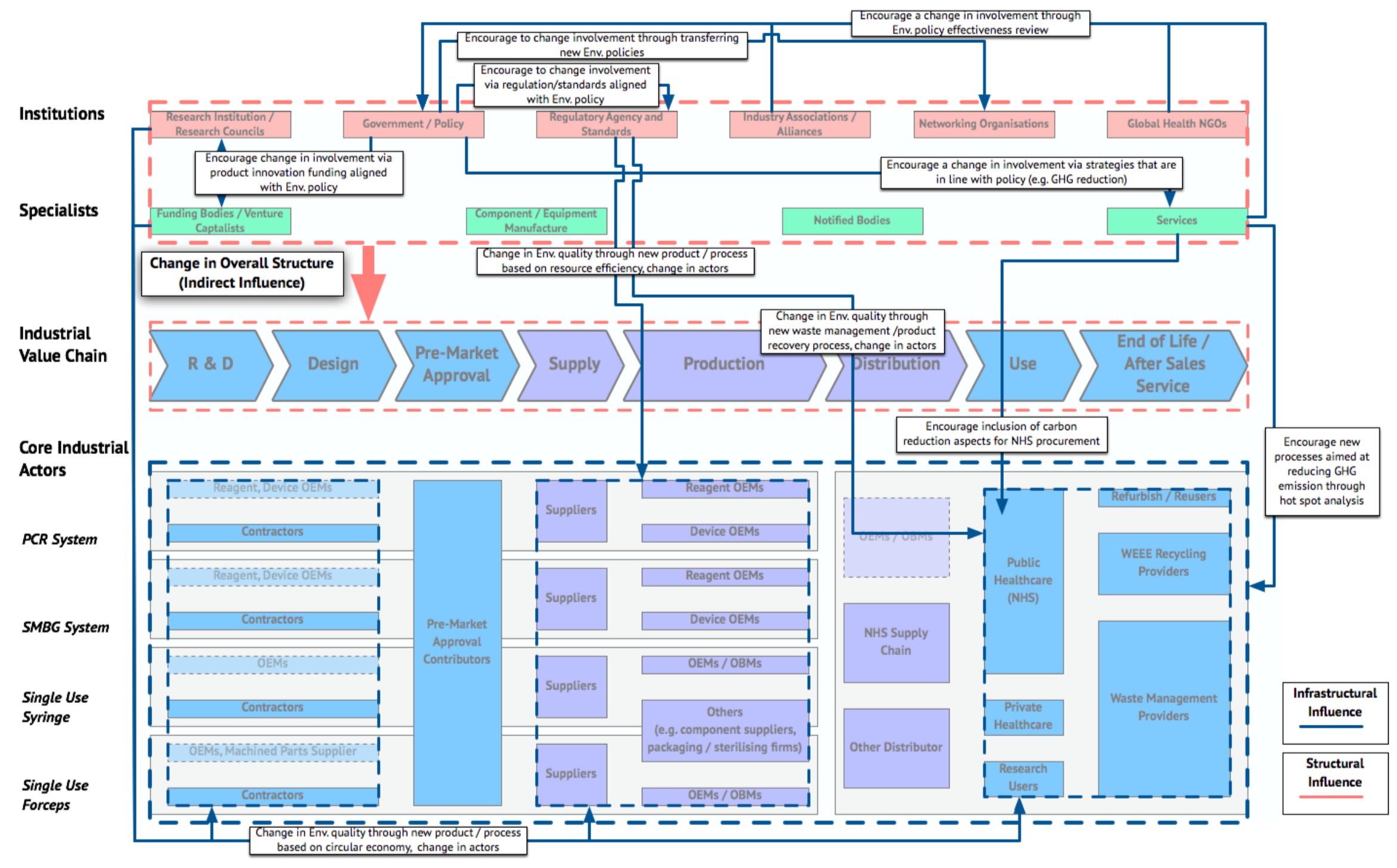

Figure 2: Influence of environmental sustainability at the institution and specialist levels 


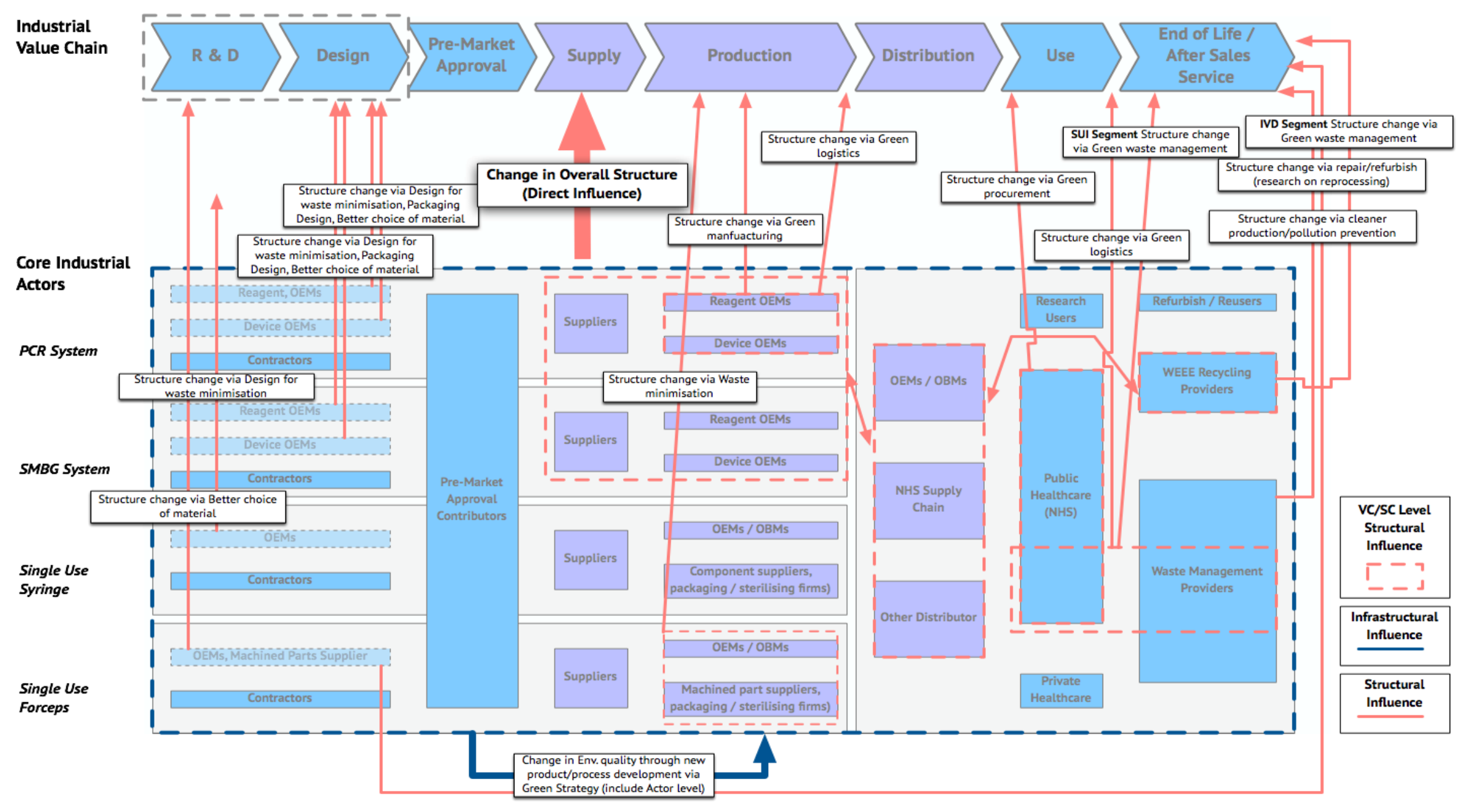

Figure 3: Influence of environmental sustainability at the Value Chain and Industrial Actor levels 


\begin{tabular}{|c|c|c|c|}
\hline & & \multicolumn{2}{|c|}{ In Vitro Diagnostic Segment } \\
\hline & & PCR System & SMBG System \\
\hline \multirow{17}{*}{ 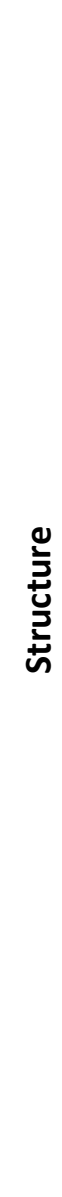 } & Product Characteristics & & \\
\hline & Technology & \multicolumn{2}{|c|}{ biotechnology, electrical, mechanical } \\
\hline & No. components & very high & high \\
\hline & $\begin{array}{l}\text { Components/materials } \\
\text { used }\end{array}$ & \multicolumn{2}{|c|}{ mix of plastic, metal, electronic component, LCD screen, internal computer, sensors, (bio)chemicals etc. } \\
\hline & value & high & medium \\
\hline & Purpose & diagnostic/research & diagnostic \\
\hline & VC/SC Processes & & \\
\hline & R\&D, Design & \multicolumn{2}{|c|}{ complicated (esp. diagnostics reagent) } \\
\hline & Pre-market Approval & $\begin{array}{l}\text { CE approval route depends on its use (research } \\
\text { diagnostic) }\end{array}$ & $\begin{array}{l}\text { device and test strip follows IVDD route whereas a } \\
\text { lancet follows the MDD for CE approval }\end{array}$ \\
\hline & Supply Chain Development & \multicolumn{2}{|c|}{ complex due to various components/material required for both instrument and reagent } \\
\hline & Production & \multicolumn{2}{|c|}{ Variety of production stage involved (machining, assembly, chemical processing etc.) } \\
\hline & Distribution & \multicolumn{2}{|c|}{ Mainly through direct to market from OEMs/OBMs, NHS Supply Chain or other distributors } \\
\hline & Market & $\begin{array}{l}\text { public/private healthcare, university /labs, } \\
\text { biotech/pharma companies etc. }\end{array}$ & mainly public / private healthcare and pharmacies \\
\hline & $\begin{array}{l}\text { End of life / After Sales } \\
\text { Service }\end{array}$ & $\begin{array}{l}\text { refurbish/remanufacturing/reuse, recycling, } \\
\text { incinerate/landfill }\end{array}$ & recycling, incinerate/landfill \\
\hline & Capacity & & \\
\hline & R\&D, Design & \multicolumn{2}{|c|}{ relatively high capacity from industrial actors as well as external stakeholders } \\
\hline & Pre-market Approval & \multicolumn{2}{|c|}{ higher capacity due to emerging sector } \\
\hline
\end{tabular}




\begin{tabular}{|c|c|c|c|}
\hline & Supply Chain Development & $\begin{array}{l}\text { low capacity for reagents (mainly from Europe) } \\
\text { moderate capacity for research use instrument (sourced } \\
\text { locally) }\end{array}$ & $\mathrm{n} / \mathrm{a}$ \\
\hline & Production & \multicolumn{2}{|c|}{ higher production capacity on reagents } \\
\hline & Distribution & \multicolumn{2}{|c|}{ highest capacity through direct to market } \\
\hline & Market & \multicolumn{2}{|c|}{ higher reagent capacity than instrument (esp. research use in the case of PCR) } \\
\hline & $\begin{array}{l}\text { End of life / After Sales } \\
\text { Service }\end{array}$ & \multicolumn{2}{|c|}{ highest capacity on recycling } \\
\hline & Product Imports/Exports & $\begin{array}{l}\text { higher import capacity than exports (some reagent } \\
\text { exports) }\end{array}$ & $\begin{array}{l}\text { almost exclusive imports for UK market (some } \\
\text { reagent exports) }\end{array}$ \\
\hline & Roles and Relationship & & \\
\hline & Institutions & \multicolumn{2}{|c|}{ various interactions within different institutions as well as with industrial actors } \\
\hline & Specialists & \multicolumn{2}{|c|}{$\begin{array}{c}\text { various interactions with a specific player of the value chain as well as with industrial actors (e.g. direction of } \\
\text { research funding) }\end{array}$} \\
\hline & Industrial Actors & \multicolumn{2}{|c|}{$\begin{array}{l}\text { main interactions with suppliers/customers as well as with stakeholders (e.g. research partnerships, regulation, } \\
\text { lobbying) }\end{array}$} \\
\hline & Technology & & \\
\hline & Production & mainly manual method (e.g. mixing, machining) involved & $\begin{array}{l}\text { mix of manual (for device) and automated (for test } \\
\text { strip) }\end{array}$ \\
\hline & Communication & \multicolumn{2}{|c|}{ mix of IT and manual data communication } \\
\hline \multirow{4}{*}{ 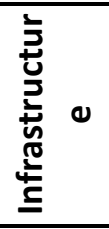 } & Industrial Actors & & \\
\hline & R\&D, Design & \multicolumn{2}{|c|}{ mix of MNCs, SMEs and ODMs } \\
\hline & Pre-market Approval & \multicolumn{2}{|c|}{ generally more parties involved (e.g. NICE, MHRA) due to the innovative nature of the devices } \\
\hline & Supply Chain Development & \multicolumn{2}{|c|}{ low US based supplier from most production occurring globally } \\
\hline
\end{tabular}




\begin{tabular}{|c|c|c|}
\hline Production & $\begin{array}{l}\text { high ratio of geographical presence of MNCs although } \\
\text { only on company with production facility in the UK was } \\
\text { observed } \\
\text { moderate ratio of UK OEMs for reagent production }\end{array}$ & $\begin{array}{l}\text { high ratio of geographical presence of MNCs } \\
\text { although only one company with production facility } \\
\text { in the UK was observed } \\
\text { very few UK OEM presence }\end{array}$ \\
\hline Distribution & \multicolumn{2}{|c|}{ Similar actor types (OEMs, OBMs for direct to market, NHS Supply Chain and other distributors) } \\
\hline Market & $\begin{array}{l}\text { Various users involved due to the multiple device use } \\
\text { nature (diagnostic of research) }\end{array}$ & \\
\hline $\begin{array}{l}\text { End of life / After Sales } \\
\text { Service }\end{array}$ & Various actors involved due to many end of life options & \\
\hline \multicolumn{3}{|l|}{$\begin{array}{l}\text { External Stakeholder } \\
\text { Involvement }\end{array}$} \\
\hline \multirow{2}{*}{ Institutions } & \multicolumn{2}{|c|}{$\begin{array}{l}\text { high involvement of product related research (mainly biotechnology rather than mechanical/electrical } \\
\text { high involvement of global health NGOs due to epidemic nature of immunology / diabetes } \\
\text { focus of regulation is due to the risk of devices from the interpretation of test results }\end{array}$} \\
\hline & $\begin{array}{c}\text { legislation difference between diagnostics and research } \\
\text { use devices (IVDD vs. EMCD \& LVD) }\end{array}$ & $\begin{array}{l}\text { further focus on accuracy of data and reliability due } \\
\text { to self-testing nature of product (ISO 15197) }\end{array}$ \\
\hline Specialists & \multicolumn{2}{|c|}{ more commercial findings are available and more component/ equipment manufactures } \\
\hline & $\begin{array}{l}\text { relatively complex overall notified body involvement due } \\
\text { to difference in device use }\end{array}$ & $\begin{array}{l}\text { relative complex overall notified body involvement } \\
\text { due to difference in component purpose }\end{array}$ \\
\hline Product / Service Quality & & \\
\hline Quality & \multicolumn{2}{|c|}{$\begin{array}{l}\text { high quality is maintained through strict regulations and quality management standards (e.g. ISO 9001/13485) } \\
\text { due to concern on health \& safety of patients }\end{array}$} \\
\hline $\begin{array}{l}\text { New Product / Process } \\
\text { Development }\end{array}$ & & \\
\hline
\end{tabular}




\begin{tabular}{|l|l|c|} 
New Product & $\begin{array}{c}\text { focus on next-generation sensing technology, safety and } \\
\text { comfort }\end{array}$ & $\begin{array}{c}\text { focus on next-generation sensing technology, safety } \\
\text { and comfort }\end{array}$ \\
\cline { 2 - 3 } New Process & $\begin{array}{c}\text { new process to prepare for the new IVD, MD Directive } \\
\text { (ongoing review since 2012) }\end{array}$ & $\begin{array}{c}\text { new process to prepare for the new IVD, MD } \\
\text { Directive (on-going review since 2012 }\end{array}$ \\
\hline
\end{tabular}




\begin{tabular}{|c|c|c|c|}
\hline & & \multicolumn{2}{|c|}{ Single Use Segment } \\
\hline & & Single Use Syringe & Single Use Forceps \\
\hline \multirow{19}{*}{ 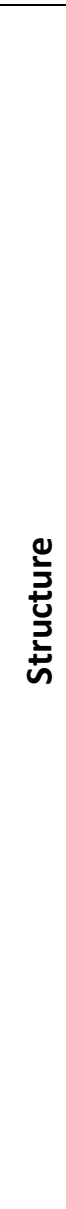 } & Product Characteristics & & \\
\hline & Technology & \multicolumn{2}{|c|}{ mechanical } \\
\hline & No. components & low & few \\
\hline & $\begin{array}{l}\text { Components/materials } \\
\text { used }\end{array}$ & mix of plastics, rubber, metal etc., & metal (e.g. stainless steel) \\
\hline & value & \multicolumn{2}{|c|}{ low } \\
\hline & Purpose & \multicolumn{2}{|c|}{ clinical } \\
\hline & VC/SC Processes & & \\
\hline & R\&D, Design & moderate & simple \\
\hline & Pre-market Approval & both follows the MDD route for CE approval & \\
\hline & Supply Chain Development & relatively simple since several components/materials required & simple due to only metal in required \\
\hline & Production & main production stages include needle and plastic moulding & various different machining stages (mainly outsourced) \\
\hline & Distribution & \multicolumn{2}{|c|}{ Mainly through direct to market from OEMs/OBMs, NHS Supply Chain or other distributors } \\
\hline & Market & \multicolumn{2}{|c|}{ mainly public/private healthcare } \\
\hline & $\begin{array}{l}\text { End of life / After Sales } \\
\text { Service }\end{array}$ & primary incinerate/landfill & mix of recycling and incinerate/landfill \\
\hline & Capacity & & \\
\hline & R\&D, Design & relatively low & low \\
\hline & Pre-market Approval & \multicolumn{2}{|c|}{ relatively low capacity due to established field } \\
\hline & Supply Chain Development & $\mathrm{n} / \mathrm{a}$ & low capacity (mainly from East Asia and Europe) \\
\hline & Production & more Globally than UK & low machining capacity (due to majority outsourced) \\
\hline
\end{tabular}




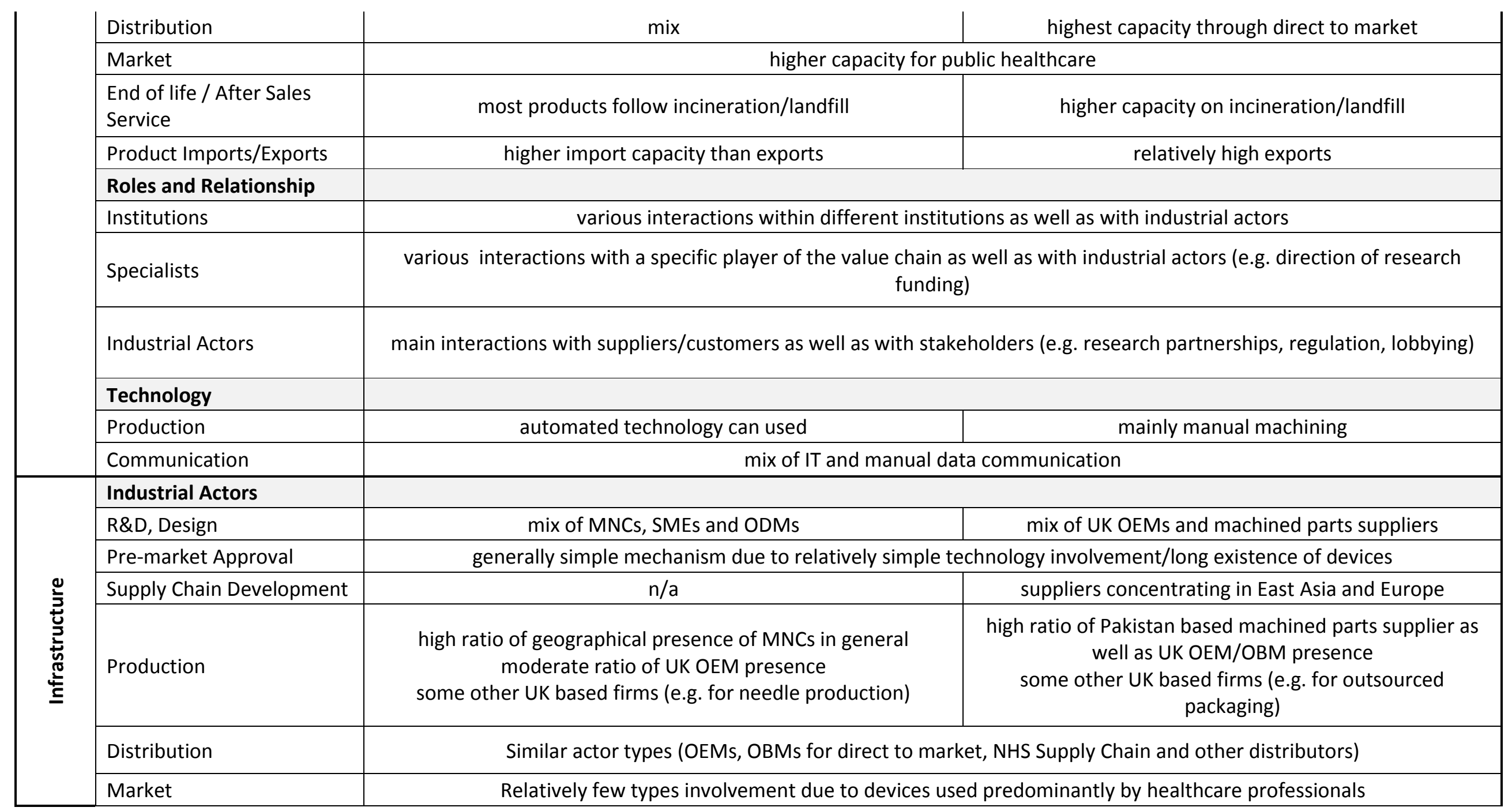




\begin{tabular}{|c|c|c|}
\hline $\begin{array}{l}\text { End of life / After Sales } \\
\text { Service }\end{array}$ & Generally only one end of life player type & Multiple actors involved from more than one end of life \\
\hline \multicolumn{3}{|l|}{$\begin{array}{l}\text { External Stakeholder } \\
\text { Involvement }\end{array}$} \\
\hline \multirow{2}{*}{ Institutions } & \multicolumn{2}{|c|}{$\begin{array}{l}\text { Research focus on health \& safety aspects (e.g. decontamination) } \\
\text { high involvement of regulators and trade unions regarding health \& safety of product users } \\
\text { focus of regulation is due to the risk of devices from the potential physical harm to the patient/users }\end{array}$} \\
\hline & $\begin{array}{l}\text { further focus on blood-borne disease: The Sharps Regulation } \\
\text { (Sharps instruments in Health care) Regulations } 2013\end{array}$ & further focus on reprocessing instruments \\
\hline \multirow{2}{*}{ Specialists } & \multicolumn{2}{|c|}{ relatively lower involvement compared to IVD a sector } \\
\hline & $\begin{array}{l}\text { relatively complex notified body involvement from various ISO } \\
\text { standards that may be applicable }\end{array}$ & relatively simple notified body structure \\
\hline \multicolumn{3}{|l|}{ Product / Service Quality } \\
\hline Quality & \multicolumn{2}{|c|}{$\begin{array}{l}\text { high quality is maintained through strict regulations and quality management standards (e.g. ISO 9001/13485) due to } \\
\text { concern on health \& safety of patients }\end{array}$} \\
\hline \multicolumn{3}{|l|}{$\begin{array}{l}\text { New Product / Process } \\
\text { Development }\end{array}$} \\
\hline New Product & $\begin{array}{l}\text { focus on safety/shielding mechanism, new drug delivery } \\
\text { methods (e.g. needle-free) }\end{array}$ & $\begin{array}{l}\text { focus on new material and customer design } \\
\text { requirements }\end{array}$ \\
\hline New Process & \multicolumn{2}{|c|}{ new process to prepare for the new MD Directive (on-going review since 2012) } \\
\hline
\end{tabular}




\begin{tabular}{|c|c|c|}
\hline & \multicolumn{2}{|c|}{ In Vitro Diagnostic Segment } \\
\hline & PCR System & SMBG System \\
\hline \multicolumn{3}{|c|}{ Institution/Specialist Level } \\
\hline Policy & \multicolumn{2}{|c|}{$\begin{array}{l}\text { focus on green economy: encourage resource efficiency and environmental management, promotion of eco-Innovation. } \\
\text { Improving the sustainable consumption. focus on waste/product recovery, and to achieve } 80 \% \text { GHG reduction by } 2050\end{array}$} \\
\hline Strategy & \multicolumn{2}{|c|}{$\begin{array}{l}\text { developing medical technology industrial strategy for Climate Change National Adaptation Plan as well as more specific } \\
\text { strategies regarding each product from the highlights on specific carbon hotspots (by SDU) }\end{array}$} \\
\hline Regulation & \multicolumn{2}{|c|}{$\begin{array}{l}\text { setting regulations in line with above policy as well as ensuring a balance between health \& safety aspects } \\
\text { to improve product recovery (e.g. setting landfill tax ( } 80 \text { pounds per tonne) to divert waste from landfill and regulating } \\
\text { exports to avoid leakage of valuable material) }\end{array}$} \\
\hline Funding & \multicolumn{2}{|c|}{ funding research on all TRL. that support circular economy principle } \\
\hline Knowledge Transfer & \multicolumn{2}{|c|}{$\begin{array}{l}\text { to provide strategy. guidance and tools to industrial actors as well as external stakeholders to support environmental } \\
\text { policies }\end{array}$} \\
\hline Lobbying & \multicolumn{2}{|c|}{$\begin{array}{c}\text { consultation to align UK environmental sustainability polity amnion with EU level } \\
\text { consultation regarding landfill taxation policy to incentivize products that are designed to have lower environmental } \\
\text { impact and support greater reuse/repair } \\
\text { possible Inclusion of environmental aspects in the HTA from NICE }\end{array}$} \\
\hline \multicolumn{3}{|c|}{ Value/ Supply Chain Level } \\
\hline Green Manufacturing & waste minimisation (MNC) & \\
\hline Green Procurement & \multicolumn{2}{|c|}{ more sustainable consumption through inclusion of carbon reduction aspects for NHS procurement (UK user) } \\
\hline & \multicolumn{2}{|c|}{ sustainable consumption through inclusion of IVD EEE for EU Green Public Procurement Guideline (UK user) } \\
\hline Green logistics & \multicolumn{2}{|c|}{$\begin{array}{c}\text { reduction of carbon footprint through achieving carbon fleet neutral through carbon reduction aspects for NHS } \\
\text { procurement (UK user) }\end{array}$} \\
\hline
\end{tabular}




\begin{tabular}{|c|c|c|}
\hline & $\begin{array}{l}\text { Reduce waste and carbon footprint via reduction of } \\
\text { refrigerant for reagent transport(MNC) }\end{array}$ & \\
\hline \multicolumn{3}{|l|}{ Green Waste Management } \\
\hline Green Strategy & \multicolumn{2}{|c|}{$\begin{array}{l}\text { reduction of carbon footprint through investigating carbon 'hot spots' for a particular product (UK manufacture) } \\
\text { increased product recovery from further bringing back sterilisation to the hospitals (e.g., Hospital StenInation and } \\
\text { Disinfection Unit. HSDU) } \\
\text { improved resource efficiency and wage through E-procurement strategies leading to lower via paperless system (e.g. } \\
\text { UDI GSI compliant barcodes) }\end{array}$} \\
\hline $\begin{array}{l}\text { Emended Producer } \\
\text { Responsibility }\end{array}$ & \multicolumn{2}{|c|}{ Increase In product recovery/resource efficiency through compliance to WEEE. RoHs directive (IVD actors) } \\
\hline $\begin{array}{l}\text { Shared Risk and Benefits/ } \\
\text { Knowledge Sharing }\end{array}$ & \multicolumn{2}{|c|}{$\begin{array}{l}\text { overall Improvement through collaboration with other industrial actors (e.g. OEMs, NHS, waste management firms) } \\
\text { (Industrial actors) }\end{array}$} \\
\hline \multicolumn{3}{|l|}{ Industrial Actors Level } \\
\hline \multicolumn{3}{|l|}{ Eco Design } \\
\hline Design for waste minimisation & $\begin{array}{l}\text { reducing waste from reducing power usage of } \\
\text { instruments (SME) } \\
\text { research and production of freeze dried reagents that } \\
\text { can significantly reduce carbon fleet (SME) }\end{array}$ & $\begin{array}{l}\text { reducing waste from designing a SMBG system using } \\
\text { significantly less consumables (MNC) } \\
\text { reducing waste through smaller, lighter packaging (MNC) }\end{array}$ \\
\hline Package Design & $\begin{array}{l}\text { research and implementation of biodegradable } \\
\text { packaging to eliminate waste (MNC) }\end{array}$ & \\
\hline Better choice of material & $\begin{array}{l}\text { research and implementation of sustainable material } \\
\text { (bioplastics)for reagent packaging (MNC) }\end{array}$ & $\begin{array}{l}\text { increasing product through the use of sustainable material } \\
\text { for packaging materials (MNC) }\end{array}$ \\
\hline Product Recovery & & \\
\hline
\end{tabular}




\begin{tabular}{|c|c|c|}
\hline \multicolumn{3}{|l|}{ Reuse } \\
\hline \multicolumn{3}{|l|}{ Green Production } \\
\hline $\begin{array}{l}\text { Clean Production/Pollution } \\
\text { Prevention }\end{array}$ & \multicolumn{2}{|c|}{$\begin{array}{l}\text { increase in environmental management through using less polluting hydroclave as an alternative to incineration (end of } \\
\text { life firm) } \\
\text { recovering energy from incinerating healthcare waste (end of life firm) }\end{array}$} \\
\hline \multicolumn{3}{|l|}{ Green Corporate Policy/Strategy } \\
\hline \multicolumn{3}{|l|}{$\begin{array}{l}\text { Beyond } \\
\text { compliance/Environment } \\
\text { Leadership }\end{array}$} \\
\hline \multicolumn{3}{|l|}{ Renewable energy sourcing } \\
\hline $\begin{array}{c}\text { Implementation of } \\
\text { EMS/Regulatory compliance }\end{array}$ & $\begin{array}{l}\text { implementation of EMS through the use of green funding } \\
\text { (SME) } \\
\text { compliance to revised regulation with anticipated } \\
\text { increase in toxicity of future reagents (SME) }\end{array}$ & \\
\hline Environmental accounting (LCA) & & \\
\hline
\end{tabular}


Table 8: Environmental sustainability focus and challenges (Cross-case analysis) - Single Use Segment

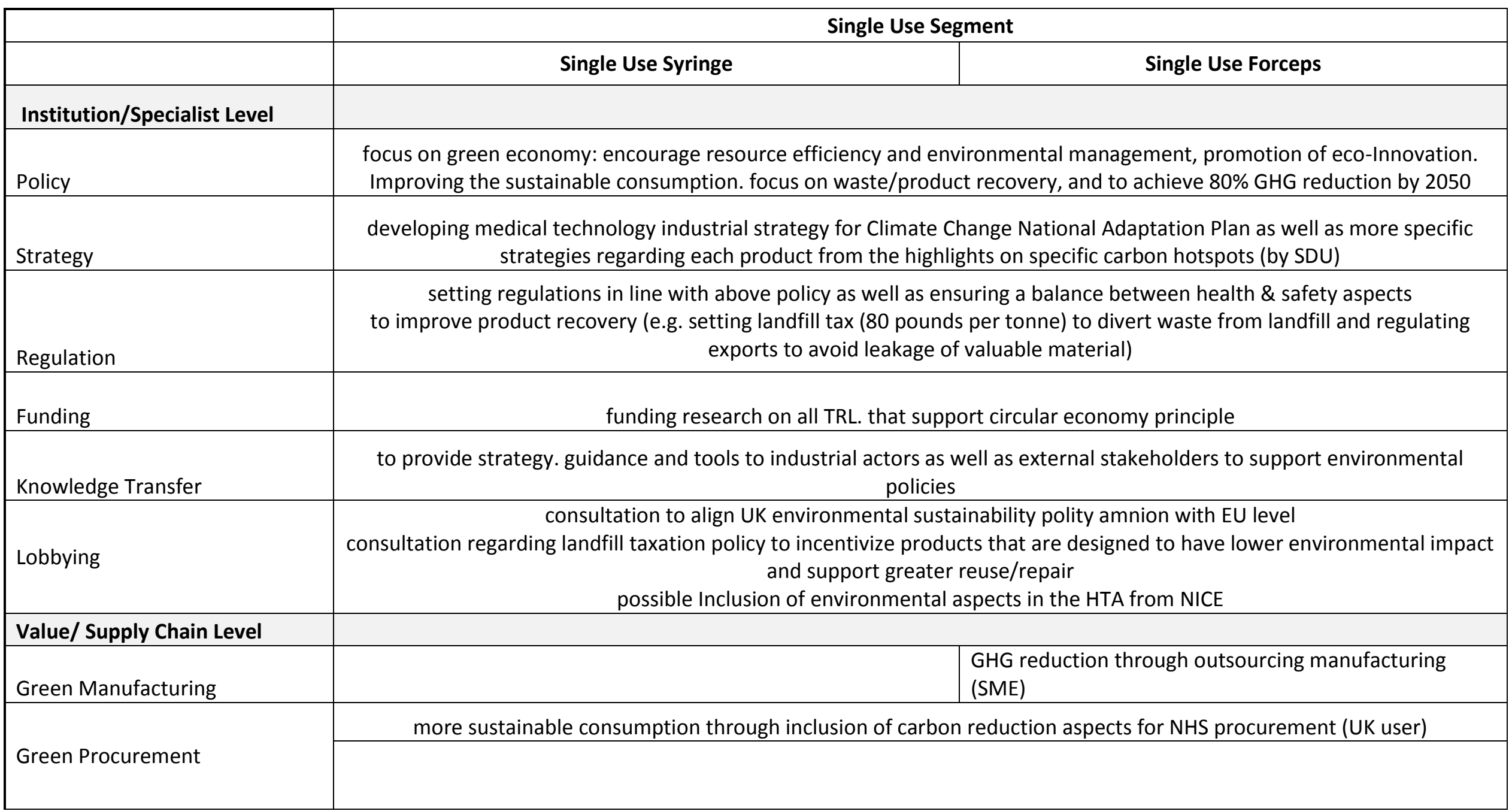




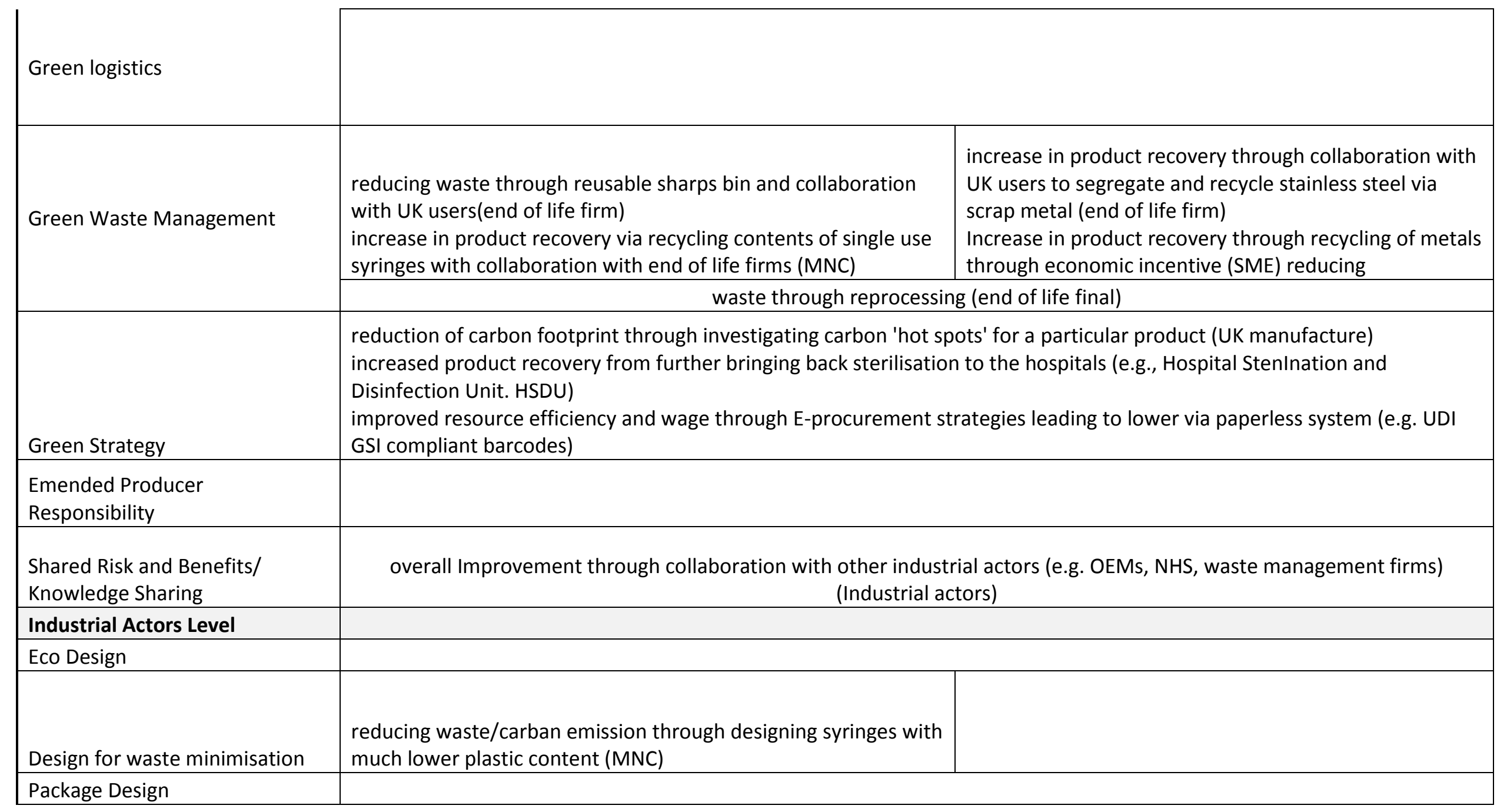




\begin{tabular}{|c|c|c|}
\hline Better choice of material & & $\begin{array}{l}\text { reduction in carbon footprint through research to } \\
\text { substitute stainless steel into polymer to justify on- } \\
\text { shoring via automation (SME) }\end{array}$ \\
\hline \multicolumn{3}{|l|}{ Product Recovery } \\
\hline Reuse & & $\begin{array}{l}\text { Future research on reprocessing in order to assess its } \\
\text { contamination issue }\end{array}$ \\
\hline \multicolumn{3}{|l|}{ Green Production } \\
\hline $\begin{array}{l}\text { Clean Production/Pollution } \\
\text { Prevention }\end{array}$ & \multicolumn{2}{|c|}{$\begin{array}{l}\text { increase in environmental management through using less polluting hydroclave as an alternative to incineration (end of life } \\
\text { firm) } \\
\text { recovering energy from incinerating healthcare waste (end of life firm) }\end{array}$} \\
\hline \multicolumn{3}{|l|}{ Green Corporate Policy/Strategy } \\
\hline \multicolumn{3}{|l|}{ Eco-efficiency } \\
\hline \multicolumn{3}{|l|}{$\begin{array}{l}\text { Beyond } \\
\text { compliance/Environment } \\
\text { Leadership }\end{array}$} \\
\hline \multicolumn{3}{|l|}{ Renewable energy sourcing } \\
\hline \multicolumn{3}{|l|}{$\begin{array}{l}\text { Selection of pollution prevention } \\
\text { strategy }\end{array}$} \\
\hline $\begin{array}{l}\text { Implementation of } \\
\text { EMS/Regulatory compliance }\end{array}$ & \multicolumn{2}{|c|}{$\begin{array}{c}\text { implementing EMS (e.g ISO 14001) to a number of actors, especially SMEs and others wishing to become a waste } \\
\text { management provider (can be through green funding opportunities }\end{array}$} \\
\hline Environmental accounting (LCA) & $\begin{array}{l}\text { performing LCA to investigate the trade-off between benefit } \\
\text { gained from recycling, additional transportation and } \\
\text { refurbishment of material, etc.(MNC) }\end{array}$ & $\begin{array}{l}\text { LCA activities to compare carbon footprint of } \\
\text { outsourcing manufacturing to UK manufactured goods } \\
\text { (SME) }\end{array}$ \\
\hline
\end{tabular}




\section{Discussion}

\subsection{UK Medical Technology Sector Industrial System}

\subsubsection{Structural Characteristics}

Product Characteristics: Both PCR system and SMBG system in the IVD segment are based on a number of technologies (electrical, mechanical and biotechnology) due to the product nature involving an instrument and a reagent. This results in a high number of components and materials used; plastic, metal, electronic components, LCD screen, internal computer, sensors, (bio) chemicals etc. Both products are used for a diagnostic purpose, however the PCR system is used heavily for research as well. For the single use segment, both syringe and forceps are mainly mechanical technology based. Compared to the forceps involving only stainless steel, a syringe involves a mix of plastic, rubber, metal etc. Both products are low value compared to the IVD products analysed and it is mainly used for clinical purpose in public/private healthcare.

Value/Supply Chain Process, Capacity and Technology: From the two case studies on the IVD segment, it was observed that the VC/SC processes involved were complex in comparison to the SUI segment due the various technologies and the number of components involved. One difference between the two IVD products was found in the pre-market approval stage. PCR system will follow a different CE approval route depending on its intended use for research or diagnostic, in which the latter involves a more rigorous process through IVDD from the health \& safety risk of the patients. SMBG system involves two routes as well, in which the device/test strip has to comply with the IVDD, whereas the lancet follows the MDD route from the different risks it poses to the patient.

From the number of components involved for the two IVD products, a complicated component/material sourcing and a variety of production stages (e.g. machining, assembly, chemical processing) are involved. For a PCR system, materials for reagents are mainly sourced from a variety of suppliers in Europe resulting in a low UK capacity. However, components for the research use instruments are sourced locally where possible, resulting in a higher capacity. For production, there is a difference in structure in which there are more reagent OEMs, resulting in a higher capacity for them. Although there are many similarities between the two IVD products, one difference is in the reagent production technology. It was stated by an R\&D Manager of a PCR Reagent Manufacture, "Even in a MNC, manual mixing methods are common", whereas automation is common for SMBG test strips (Gebel, 2012). Another difference between the two is that PCR reagents generally require a refrigerated transport through inclusion of dried ice.

The products share a common market of public/private healthcare for clinical diagnostic purpose. There are additional markets involved for both products in which; PCR system 
is used in universities/labs or biotechnology/pharmaceutical companies for research, and SMBG system is sold in pharmacies for general public use. In both cases, there is a higher market capacity for the reagents rather than instruments due to its consumable nature. At the end of life, both instruments are most commonly recycled due to the WEEE legislation. In some cases, it was stated from a Clinical Waste Manager of a Waste Management Provider, "Some SMBG devices will go directly into incineration if not sterilised". Furthermore, there was some indication of refurbish/remanufacturing/reuse for the PCR instruments. Reagents from both products as well as the lancet from the SMBG system are considered clinical waste and these are incinerated by high temperature and sent to landfill.

From the two case studies on the SUI segment, it was observed that the VC/SC processes involved were relatively simple in comparison to the IVD segment. For example, the R\&D and design phase of a single use forceps is generally based on an alteration of reusable instruments, stated by a Managing Director of a UK forceps manufacture. One difference between the two products is that syringe involves automated production process whereas forceps go through various manual-machining processes. This brings interesting production capacity differences. Forceps machining is mostly outsourced in Pakistan or China due to cost differences, whereas syringes can be produced in the UK since automation results in marginal cost difference. A Managing Director in a Forceps Manufacturer has stated, "If there exists a plastic with a very similar properties to the currently used metal that we can manufacture in the UK using automation that will be my Nirvana". Both products are mainly used in public healthcare (NHS) and they are predominantly incinerated due to contamination. Although uncommon, forceps can be recycled if they are segregated as the point of use. In Addenbrooke's Hospital, it was stated by an Environmental Manager, "Forceps are put into a separate transport box that will be sent for decontamination in-house and sent for scrap metal".

Roles and Relationship: Roles and relationships between institutions, specialists and industrial actors are very similar for all product-based industrial systems. Governmental bodies generally influence the research institutions and regulatory agencies via funding and policies. There is also a significant influence to the direction of polices via lobbying from industrial associations/unions (voice of industrial actors/general public) and Global Health NGOs (global health concern). The research funding mechanism can be divided into three types; research councils that fund basic research, research institutes that fund applied research and specialist funding bodies that fund potential commercialisation research. Depending on the level of research, there are frequent partnerships with NHS, universities and industrial actors.

The primary role of the regulatory agency is to regulate the medical technology industry to ensure health \& safety of the consumers as well as the actors involved in the value/supply chain. There are also influences from other external stakeholders. For 
example, a legislation to prevent injuries to healthcare workers caused by sharps, including syringes was adapted due to the influence of unions (EPSU and HOSPEEM). Another important interrelation in this area is the authorised power given to notified bodies by MHRA (UK competent authority). Notified bodies carry out certain conformity assessments required at the pre-market approval stage.

Another key actor important for the overall dynamics of an industry is the networking organisations. For example, the main role of KTN is to transfer knowledge between external stakeholders and industrial actors regarding research partnerships, regulation change, funding opportunities etc. Due to the high percentage of SMEs in the UKMTS, there are also significant specialist service activities. It was stated by the Head of Health from KTN as, "All the way along the value chain, SMEs need help through consultancy service, whereas big companies have in-house ability for various process such as R\&D and manufacturing scale up".

\subsubsection{Infrastructural Characteristics}

Industrial Actors: Generally, industrial actors involved in the R\&D and design are the OEMs. It was observed for PCR, SMBG and syringe industrial systems that some OEMs choose to outsource this stage to ODMs. From the forceps case study, it was observed that machined parts supplier could also be involved. For the pre-market approval stage, more actors are generally involved for the IVD segment since products tend to be more innovative than the SUI segment, requiring more rigorous approval stages with multiple actors. Generally, a higher geographical presence of MNCs was observed for all products except for the forceps industrial system. It is noted that most MNCs only have a sales division in the UK and only few production facilities were observed for PCR and SMBG reagents. For the forceps, there are mainly two types of UK manufactures, OEMs and OBMs in which the latter have agreements with external manufactures to put their own label. In both cases, highest portion of machined parts comes from Sialkot, Pakistan where it has a significant surgical equipment manufacturing market (Managing Director, Forceps Manufacture). Due to the product characteristics of the PCR and SMBG systems, there are various industrial actors involved in the market, whereas SUIs are primary used for clinical purpose by healthcare providers. For the end of life, waste management providers are the main actors in the syringe industrial system, whereas there are multiple actor types involved in the other three products due to the different end of life options.

External Stakeholder Involvement and Product/Service Quality: Generally, it was observed that there is a difference in the external stakeholders involved and their focus in the two segments analysed. For example, more actors are involved for the PCR and SMBG industrial system as these diagnostics functions are important in reducing immunology/diabetes epidemics. As a result, there are more research, funding opportunities and Global Health NGOs involved in these fields. For the SUIs, there is a 
high focus on contamination and blood-borne diseases. For example, Sharps Regulation was introduced from the influence of unions for this purpose. Research focuses on decontamination such as the radiofrequency (RF) gas-plasma technology developed by the University of Edinburgh to sterilise metal surgical instruments (The University of Edinburgh, 2006).

Since medical technology has a significant impact on the patient's health \& safety, the product quality is maintained through strict regulations and quality management standards (e.g. ISO 9001 / 13485) formed by the International Organization of Standardization (ISO). Due to the different risks the two segments pose to the patients, IVDD is in charge of regulatory compliance for diagnostic purpose PCR and SMBG system (excluding lancet), whereas MDD is responsible for SMBG lancet, syringe and forceps. The difference in risk was explained by a Regulatory Affairs Manager in EDMA that, "If a MD doesn't work, it can cause physical harm to a patient whereas if there is a faulty result from an IVD test (e.g. for HIV), the patient can spread the disease". Due to the user characteristics of a SMBG system as the general public, there is a further emphasis on data accuracy through ISO 15197 aiming to reduce its risks.

New Product/Process Development: The new product development focus is rather different for all products. For a PCR system, the focus is on higher efficiency (e.g. speed of test), new PCR platform or new assay test development. For a SMBG system, one focus is on next-generation sensing technology that can improve the accuracy. An injection system that does not provide discomfort is a common theme between the lancets used in SMBG system and syringes. The latter has a further focus on the shielding mechanism to protect the healthcare providers from blood-borne diseases. For the forceps, one focus is on new polymer materials that have similar strength properties to stainless steel. In terms of NPD, there is an on-going discussion since 2012 to review the current MDD and IVDD directives. These will pose a more rigorous regulation and influence the way notified body functions, ultimately affecting the individual VC/SC as well as product characteristics for all product-based industrial systems.

\subsection{Environmental sustainability Dynamics}

Environmental sustainability dynamics at the Institution/Specialist Level: Governmental policies are encouraging basic/applied research councils as well as commercial research funding to change their involvement through product innovation and funding projects that are aligned with the environmental policies. Regarding commercial funding, it was stated by the Head of Sustainability of the Technology Strategy Board - "The goal is to build sustainability and resource efficiency in the UK economy through mainly funding projects that are relative to the circular economy and assist in transforming the industrial system". These research/funding activities aim to influence industrial actors in an infrastructural way through encouraging a change in product/service quality, new products/processes based on the circular economy, change of actors etc. Environmental policies are influencing regulators to change their involvement with industrial actors 
through setting revised regulations and standards. Another example of an infrastructural influence of environmental policies and legislation can be seen from the Sustainable Development Unit (SDU). SDU is a specialist service provider that develops tools, strategies and research that will enable UKMTS actors to promote sustainable development. The SDU's Head of Unit stated, "Due to the UK being the only European country which has a legislation on the carbon footprint reduction from the Climate Change Act, it was a good entry point for SDU to first tackle this, whereas other EU countries may be looking at toxicity first". There are various other infrastructural influences regarding environmental sustainability at the institution/specialist level that are captured in figure 2. It can be concluded that the majority of the environmental sustainability activities in the institutional/specialist level are aimed to influence the structure of the UKMTS System indirectly.

Environmental sustainability dynamics at VC/SC and Industrial Actor Levels: It was observed that infrastructural influences from the institutions/specialists could be translated into green strategies, which will encourage new processes/products to be developed internally. An example is the E-procurement strategy revised to be placed between different actors along the supply chain in order to influence the infrastructure by encouraging a more resource efficient procurement process, stated by a Senior Quality Manager, Forceps Manufacture. Comparing SMEs and MNCs, a different approach to environmental sustainability was observed. A Sustainable Policy Assistant from a Medical Technology MNC has stated, "Amongst medical technology companies, all comply with environmental legislation, with some looking at it as an opportunity such as Johnson \& Johnson (J\&J), Baxter and BD”. In contrast, it was stated by a Policy Advisor in the Association of British Healthcare Industry (ABHI), "With most UK based medical device companies being SMEs, there is not a high focus on environmental sustainability compared to other industries such as Food and Retail". For example, it was observed that SMEs had a lower implementation rate for environmental management system such as ISO 14001 compared to the MNCs. However, it was found from an interview with a Manager of a PCR Instrument Supplier that they have implemented ISO 14001 to reduce their carbon footprint from the funding scheme - 'Low Carbon Keep Project', supported by the European Regional Development Fund. Outcomes from the new product/processes developed from the influence of green strategies in both VC/SC and industrial actor level were observed to have structural influence (e.g. product characteristics, VC/SC process, capacity) targeted at certain parts of the value/supply chain. Due to the nature of waste generated through consumables used in the PCR and SMBG system, emphasis on the resource efficiency through eco design were observed. Similarly for the SMBG system, some companies are also looking into design for waste minimisation. For example, Roche has introduced a SMBG system that uses a cartridge system containing 50 tests, reducing the need to dispose each test strip. There are other companies looking into similar methods, and these activities can potentially have a structural influence on the product specific industrial system. Compared to the PCR and SMBG systems that have a 
relatively effective recycling system implemented due to regulatory compliance, product recovery for syringes and forceps are considered to be poor. A Managing director of a Forceps Manufacturer has stated, "Single use forceps are usually made from 401 stainless steel, which has fair second hand value that can be used for kitchen knives, but there is a massive gap in the UK market for recycling". The main reason for this was explained by a Clinical Waste Manager in a Waste Management Provider as, "The challenge is within proper segregation at the source to stop material from getting into the waste stream since the containers are not allowed to be reopened after sealing, ending up with the material being sent for incineration". This leads to the importance of $\mathrm{VC} / \mathrm{SC}$ level green waste management activity as an issue which can be resolved through partnering with a hospital to segregate, sterilise and send material to scrap for recycling. In the case of syringes, there is a high barrier to product recovery due to the significance of blood-borne diseases and the difficulty in recovering a product with multiple materials. One initiative observed was from Sharpsmart - reducing waste through reusable sharps bins, which can create a $25 \%$ reduction in the volume of plastic in sharps waste. Both forceps and syringes green waste management activities can have a structural influence on the value chain, as well as a change in roles and relations between waste management providers and hospitals. There are various other structural influences regarding environmental sustainability at the $\mathrm{VC} / \mathrm{SC} /$ actors level that are captured in figure 3.

\section{Conclusion}

The current UKMTS industrial system is not very proactive in terms of environmental sustainability in comparison to other industries such as automotive, food and retail. Analysis of the dynamics of environmental sustainability in the UKMTS industrial system illustrates that industrial actors require infrastructural influences from the existing external stakeholder to ultimately restructure the industrial system. As the UKMTS consists of $99 \%$ SMEs, this creates a significant challenge to implement environmental sustainability. It suggests there is a need that SMEs must be the central target of infrastructural influence by external stakeholders through research funding, regulation, collaboration etc. There is also specific difficulty in influencing the industrial actors through regulation in the UKMTS. There is a requirement for a more specific infrastructural influence for each product-based system from the external stakeholders, to effectively restructure the UKMTS. There are few MNCs collaborating with suppliers to identify opportunities across the value chain or hospitals and waste management companies collaborating toward increased product recovery and reduced carbon footprint? This research positions contextual/business environmental elements of operation management into more dominant elements of an operational system. This was performed through a structure and infrastructure perspective on industrial systems frameworks, with specific emphasis on its dynamics/influences when approaching an industrial scale challenge. From the analysis of dynamics between environmental sustainability and industrial systems, it was found that external stakeholders make 
infrastructural decisions that enable industrial actors to influence the industrial system structure directly through a 'carrot' and 'stick' approach. Further research on the industrial systems of the UK Medical Technology Sector and other sectors are recommended for additional support of the data as well as to justify this new approach.

\section{Appendix1}

\begin{tabular}{ll}
\hline No. & Corresponding Source \\
\hline $\mathbf{1}$ & (Glavič \& Lukman, 2007) \\
\hline $\mathbf{2}$ & (Marteel et al., 2003) \\
\hline $\mathbf{3}$ & (Joshi, 2000) \\
\hline $\mathbf{4}$ & (Orsato, 2006) \\
\hline $\mathbf{5}$ & (Linton et al., 2007) \\
\hline $\mathbf{6}$ & (Srivastava, 2007) \\
\hline $\mathbf{7}$ & (Guide et al., 2003) \\
\hline $\mathbf{8}$ & (Kleindorfer et al., 2005) \\
\hline $\mathbf{9}$ & (Vachon \& Klassen, 2006) \\
\hline $\mathbf{1 0}$ & (Wang \& Côté, 2011) \\
\hline $\mathbf{1 1}$ & (Braungart \& McDonough, 2002) \\
\hline $\mathbf{1 2}$ & (Braungart et al., 2007) \\
\hline $\mathbf{1 3}$ & (Guide \& Wassenhove, 2001) \\
\hline $\mathbf{1 4}$ & (Ferrer, 2001) \\
\hline $\mathbf{1 5}$ & (Moore et al., 2001) \\
\hline $\mathbf{1 6}$ & (Nagel \& Meyer, 1999) \\
\hline $\mathbf{1 7}$ & (Tsoulfas \& Pappis, 2006) \\
\hline $\mathbf{1 8}$ & (Platcheck et al., 2008) \\
\hline $\mathbf{1 9}$ & (Gottberg et al., 2006) \\
\hline $\mathbf{2 0}$ & (Smith \& Yen, 2010) \\
\hline $\mathbf{2 1}$ & (Wang \& Côté, 2011) \\
\hline $\mathbf{2 2}$ & (Holdway et al., 2002) \\
\hline $\mathbf{2 3}$ & (Krikke et al., 1999) \\
$\mathbf{2 4}$ & (Klemm et al., 2005) \\
\hline $\mathbf{2 5}$ & (Pol, 2010) \\
\hline $\mathbf{2 6}$ & (Martin \& Eklund, 2011) \\
\hline $\mathbf{2 7}$ & (Linton et al., 2007) \\
\hline $\mathbf{2 8}$ & (Chertow, 2000) \\
\hline & \\
\hline
\end{tabular}

\begin{tabular}{ll}
\hline 29 & (Cohen-Rosenthal, 2004) \\
\hline 30 & (Baines et al., 2012) \\
\hline 31 & (Frondel et al., 2007) \\
\hline 32 & (Vachon \& Klassen, 2006) \\
\hline 33 & (Marchi et al., 2013)
\end{tabular}




\begin{tabular}{ll}
\hline 34 & (Jacobsson \& Lauber, 2006) \\
\hline 35 & (Bovea \& Gallardo, 2006) \\
\hline 36 & (Martin \& Eklund, 2011) \\
\hline 37 & (Hwang et al., 2010) \\
\hline 38 & (Yuan et al., 2006) \\
\hline $\mathbf{3 9}$ & (Geng \& Doberstein, 2008) \\
\hline $\mathbf{4 0}$ & (Gravitis et al., 2004) \\
\hline $\mathbf{4 1}$ & (Mueller et al., 2009) \\
\hline $\mathbf{4 2}$ & (Grepperud, 2002) \\
\hline $\mathbf{4 3}$ & (Iraldo et al., 2009) \\
\hline $\mathbf{4 4}$ & (Rennings et al., 2006) \\
\hline $\mathbf{4 5}$ & (Delmas \& Montiel, 2008) \\
\hline $\mathbf{4 6}$ & (Seyfang, 2006) \\
\hline $\mathbf{4 7}$ & (Yang \& Percival, 2009) \\
\hline $\mathbf{4 8}$ & (Rondinelli \& Vastag, 2000) \\
\hline $\mathbf{4 9}$ & (Martin, 1992) \\
\hline $\mathbf{5 0}$ & (Murphy \& Gouldson, 2000) \\
\hline $\mathbf{5 1}$ & (Gouldson \& Murphy, 1996) \\
\hline $\mathbf{5 2}$ & (Erkman, 1997) \\
\hline $\mathbf{5 3}$ & (Southerton et al., 2004) \\
\hline $\mathbf{5 4}$ & (Baines et al., 2007) \\
\hline $\mathbf{5 5}$ & (Tridech \& Cheng, 2010) \\
\hline $\mathbf{5 6}$ & (Srai et al., 2013) \\
\hline
\end{tabular}

\section{References and further readings}

abhi, 2013. Annual Report 2012/2013: Innovative, safe \& effective medical technologies, London.

AGR Automation, 2014. Welcome to AGR Automation. Available at: http://www.agrautomation.com [Accessed August 29, 2014].

All-Party Parliamentary Health Group, 2013. A GUIDED TOUR OF THE NEW NHS,

AMDR, 2013. Sterilmed and Stryker Sustainability Solutions Named as "Sustainable Resources" in Greening Healthcare Facilities. Available at: http://www.amdr.org/news/2013/12/sterilmed-and-stryker-sustainability-solutionsnamed-as-"sustainable-resources"-in-greening-healthcare-facilities/ [Accessed August 20, 2014].

Anarow, B. et al., 2003. Whole-Systems Framework for Sustainable Consumption and Production, 
Anglia Ruskin University, 2014. Biomedical Research Group (BRG). Available at: http://www.anglia.ac.uk/ruskin/en/home/faculties/fst/departments/lifesciences/rese arch/brg.html [Accessed August 7, 2014].

Arthur D. Little Limited, 2005. UK Sector Competitiveness: Analysis of Six healthcare Equipment Segments,

Ashton, W.S., 2009. The Structure, Function, and Evolution of a Regional Industrial Ecosystem. Journal of Industrial Ecology, 13(2), pp.228-246.

Astech Projects, 2014. Astech Projects Automate Pre-Filled Syringe Testing with Robotic Technology. Available at: http://www.astechprojects.co.uk/company/news.php?subaction=showfull\&id=1393 502384\&archive $=\&$ start_from $=\& u c a t=1 \&$ [Accessed August 29, 2014].

Baines, T. et al., 2012. Examining green production and its role within the competitive strategy of manufacturers. Journal of Industrial Engineering and Management, 5(1), pp.53-87.

Baines, T.S. et al., 2007. State-of-the-art in product-service systems. Proceedings of the Institution of Mechanical Engineers, Part B: Journal of Engineering Manufacture, 221(10), pp.1543-1552.

BEACON, 2014. Welcome to BEACON. Available at: http://www.beaconwales.org [Accessed August 7, 2014].

Benjamin, E.M., 2002. Self-Monitoring of Blood Glucose: The Basics. Clinical Diabetes, 20(1), pp.45-47.

Bio-Rad Laboratories, 2014. qPCR Instrumentation. Available at: http://www.biorad.com/en-uk/applications-technologies/qpcr-instrumentation [Accessed August 7, 2014].

BIS, 2014. Strength and Opportunity 2013: The landscape of the medical technology, medical biotechnology, industrial biotechnology and pharmaceutical sectors in the $U K$,

BIVDA, 2014. BIVDA MEMBERS LIST 2014.

Bolton, N., 2014. List of Surgical Forceps. eHow. Available at: http://www.ehow.com/list_6950537_list-surgical-forceps.html [Accessed August $5,2014]$.

Boons, F.A.A. \& Baas, L.W., 1997. Types of industrial ecology: the problem of coordination. , 5(1-2), pp.79-86.

Bovea, M.D. \& Gallardo, a., 2006. The influence of impact assessment methods on materials selection for eco-design. Materials \& Design, 27(3), pp.209-215. 
Braungart, M. \& McDonough, W., 2002. Cradle to Cradle. Remaking the Way We Make Things First., Vintge.

Braungart, M., McDonough, W. \& Bollinger, A., 2007. Cradle-to-cradle design: creating healthy emissions - a strategy for eco-effective product and system design. Journal of Cleaner Production, 15(13-14), pp.1337-1348.

Brusoni, S., Jacobides, M.G. \& Prencipe, A., 2009. Strategic dynamics in industry architectures and the challenges knowledge integration. European Management Review, 6, pp.209-216.

Bustin, S. a, 2010. Developments in Real-Time PCR Research and Molecular Diagnostics. Expert review of molecular diagnostics, 10(6), pp.713-5.

Cairns, E., 2014. Medtech 2013 in Review,

Calder, D., 2014. An introduction to UK Funding for Innovative Med Tech Businesses. In Med-Tech Innovation Expo 2014. KTN - Health Tech and Medicines.

Calistri-yeh, M. et al., 2011. BD ecoFinity Life Cycle Solution Turning a waste stream into a resource stream: Landfill diversion and recycling of sharps waste,

Cambridge Consultants, 2012. New eco-friendly breed of medical devices.

Cambridge Sensors, 2009. Cambridge Sensors Limited: About us. Available at: http://www.cs-limited.co.uk/about-us/about-us [Accessed August 29, 2014].

Chaudhry Surgical Production Supplies, 2010. RODUCTION PROCEDURES. Available at: http://www.chaudhrysurgical.com/quality_assurance.php [Accessed August 8, 2014].

Cheetham, B. \& Johnson, A., 2013. Syringes and Sustainability: Planet, People, Profit, Liverpool.

Chertow, M.R., 2000. Industrial Symbiosis: Literature and Taxonomy.

Clarke, S.F. \& Foster, J.R., 2012. A history of blood glucose meters and their role in self-monitoring of diabetes mellitus. British Journal of Biomedical Science, 69(2), pp.83-93.

Cohen-Rosenthal, E., 2004. Making sense out of industrial ecology: a framework for analysis and action. Journal of Cleaner Production, 12(8-10), pp.1111-1123.

Crook, D., 2010. Can rapid integrated Polymerase Chain reaction (PCR)-based diagnostics for gastrointestinal pathogens and direct sequence typing of Clostridium difficile improve routine Hospital Infection Control practice?, Oxford.

DCLG, 2012. Enterprise Zones,

Defra, 2011. Government Review of Waste Policy in England 2011, 
Delmas, M. \& Montiel, I., 2008. The Diffusion of Voluntary International Management Standards: Responsible Care, ISO 9000, and ISO 14001 in the Chemical Industry. The Policy Studies Journal, 36(1), pp.65-93.

DG ENTR, 2007. REACH in brief,

DG SANCO, 2012. GUIDELINES ON MEDICAL DEVICES: IVD Medical Device Borderline and Classification issues,

DG SANCO, 2010. MEDICAL DEVICES: Guidance document - Classification of medical devices,

Diabetes UK, 2013. Better Futures: Our Annual Report 2013, London.

Diabetes UK, 2014. RESEARCH. Available at: http://www.diabetes.org.uk/Research/ [Accessed August 7, 2014].

DiCristina, J., 2010. Blood Glucose Meters. Available at: http://www.maximintegrated.com/en/app-notes/index.mvp/id/4659 [Accessed August 7, 2014].

EDMA, 2013. A Need for Separate Legislation: EDMA analysis of proposed Regulation on in vitro diagnostic medical devices,

Elkington, J., 1999. Cannibals with Forks: Triple Bottom Line of 21st Century Business New Ed., Capstone.

Ellen Macarthur Foundation, 2013. Towards The Circular Economy: Oportunities for the consumer goods sector,

Enterprise Directorate-General, 2004. IVD GUIDANCE: Research Only products,

Environmental Audit Committee, 2014. Growing a circular economy: Ending the throwaway society, London.

Erkman, S., 1997. Industrial ecology: an historical view. Journal of Cleaner Production, 5(1-2), pp.1-10.

Eucomed, 2009. Eucomed White Paper on the reuse of single use devices,

Evans, S. et al., 2009. Towards a sustainable industrial system: With recommendations for education, research, industry and policy, Cambridge: University of Cambridge Institute for Manufacturing, Department of Engineering.

Expert Group, 2014. Expert Medical Systems. Available at: http://expertamt.com/medical.html [Accessed August 29, 2014].

Ferrer, G., 2001. On the widget remanufacturing operation. European Journal of Operational Research, 135(2), pp.373-393. 
Fiksel, J., 2003. Designing resilient, sustainable systems. Environmental science \& technology, 37(23), pp.5330-9.

Frondel, M., Horbach, J. \& Rennings, K., 2007. End-of-Pipe or Cleaner Production? An Empirical Comparison of Environmental Innovation Decisions Across OECD Countries. Business Strategy and the Environment, 584(8), pp.571-584.

Frosch, A. \& Gallopoulos, N.E., 1989. Strategies for Manufacturing. Scientific American, 261, pp.144-152.

Frost \& Sullivan, 2011. European PCR Reagent Market for Research Applications and Clinical Diagnostics, London.

G W Butler, 2014. Welcome to the GWB Website. Available at: http://www.gwb.co.uk [Accessed August 8, 2014].

Garner, A., 1995. Industrial Ecology : An Introduction. , (November).

Gebel, E., 2012. Anatomy of a Test Strip. American Diabetes Association. Available at: http://www.diabetesforecast.org/2012/jul/anatomy-of-a-test-strip.html [Accessed August 8, 2014].

Geng, Y. \& Doberstein, B., 2008. Developing the circular economy in China: Challenges and opportunities for achieving "leapfrog development." International Journal of Sustainable Development \& World Ecology, 15, pp.231-239.

Giangrasso, A.P. \& Shrimpton, D.M., 2009. Syringes. In Ratio \& Proportion Dosage Calculations. Prentice Hall, pp. 138-170.

Gill, J. \& Johnson, P., 2010. Research Methods for Managers Fourth., London: Sage Publications Ltd.

Glavič, P. \& Lukman, R., 2007. Review of sustainability terms and their definitions. Journal of Cleaner Production, 15, pp.1875-1885.

Gottberg, A. et al., 2006. Producer responsibility, waste minimisation and the WEEE Directive: case studies in eco-design from the European lighting sector. The Science of the total environment, 359(1-3), pp.38-56.

Gouldson, A. \& Murphy, J., 1996. Ecological Modernization and the European Union. Geoforum, 27(I), pp.11-21.

GOV.UK, 2014. Policies: 15policies about Environment. Available at: https://www.gov.uk/government/policies?keywords=\&topics[]=environment\&depa rtments[]=all [Accessed August 22, 2014].

Gravitis, J. et al., 2004. Clustering of bio-products technologies for zero emissions and eco-efficiency. Industrial Crops and Products, 20(2), pp.169-180. 
Grepperud, S., 2002. Voluntary environmental agreements: bargaining over more than emissions. European Journal of Political Economy, 18(3), pp.545-559.

Grosios, K., Gahan, P.B. \& Burbidge, J., 2010. Overview of healthcare in the UK. The EPMA journal, 1(4), pp.529-34.

Grundon, 2011. Grundon - the UK's largest family-owned waste management company. Available at: http://www.grundon.com [Accessed August 8, 2014].

Guide, V.D.R., Harrison, T.P. \& Van Wassenhove, L.N., 2003. The Challenge of Closed-Loop Supply Chains. Interfaces, 33(6), pp.3-6.

Guide, V.D.R. \& Wassenhove, L.N., 2001. Managing Product Returns for Remanufacturing. Production and Operations Management, 10(2), pp.142-155.

Gunderson, L.H. \& Holling, C.S., 2002. Panarchy: Understanding Transformations in Human and Natural Systems, Island Press.

Harland, C.M., Lamming, R.C. \& Cousins, P.D., 1999. Developing the concept of supply strategy. International Journal of Operations \& Production Management, 19(7), pp.650-674.

Hayes, R.H. \& Wheelwright, S.C., 1984. Restoring Our Competitive Edge: Competing Through Manufacturing, Wiley.

Healthcare Environmental Group, 2014. Healthcare Environmental Group is the largest independent full facilities waste management solutions company in the UK. Available at: http://www.healthcareenv.com [Accessed August 8, 2014].

Hislop, H. \& Hill, J., 2011. Reinventing the wheel: a circular economy for resource security, London.

HMSO, 2008. Climate Change Act 2008 (c.27), London.

Holdway, B.R., Walker, D. \& Hilton, M., 2002. Eco-design and successful packaging. Design Management Journal, 13(4), pp.45-53.

Holland, C. a \& Kiechle, F.L., 2005. Point-of-care molecular diagnostic systems--past, present and future. Current opinion in microbiology, 8(5), pp.504-9.

HSE, 2013. Health and Safety ( Sharp Instruments in Healthcare) Regulations 2013: Guidance for employers and employees,

Hughes, M.D., 2009. The business of self-monitoring of blood glucose: a market profile. Journal of diabetes science and technology, 3(5), pp.1219-23.

Hwang, Y.-D., Wen, Y.-F. \& Chen, M.-C., 2010. A study on the relationship between the PDSA cycle of green purchasing and the performance of the SCOR model. Total Quality Management \& Business Excellence, 21(12), pp.1261-1278. 
Ibbotson, S. et al., 2013. Eco-efficiency of disposable and reusable surgical instruments - a scissors case. The International Journal of Life Cycle Assessment, 18(5), pp.1137-1148.

Iraldo, F., Testa, F. \& Frey, M., 2009. Is an environmental management system able to influence environmental and competitive performance? The case of the ecomanagement and audit scheme (EMAS) in the European union. Journal of Cleaner Production, 17(16), pp.1444-1452.

Jacobides, M.G., Knudsen, T. \& Augier, M., 2006. Benefiting from innovation: Value creation, value appropriation and the role of industry architectures. Research Policy, 35, pp.1200-1221.

Jacobsson, S. \& Lauber, V., 2006. The politics and policy of energy system transformation - explaining the German diffusion of renewable energy technology. Energy Policy, 34(3), pp.256-276.

Jangam, S.R. et al., 2013. A point-of-care PCR test for HIV-1 detection in resourcelimited settings. Biosensors \& bioelectronics, 42, pp.69-75.

Johnson \& Johnson, 2013. 2013 Citizenship \& Sustainability Report,

Joshi, S., 2000. Life-Cycle Assessment Using Input-Output Techniques. Journal of Industrial Ecology, 3, pp.95-120.

Kleindorfer, P.R., Singhal, K. \& Van Wassenhove, L.N., 2005. Sustainable Operations Management. , 14(4), pp.482-492.

Klemm, D. et al., 2005. Cellulose: Fascinating Biopolymer and Sustainable Raw Material. Angewandte Chemie (International ed. in English), 44(22), pp.33583393.

Kravetz, R.E., 2005. Hypodermic Syringe. The American journal of gastroenterology, 100(12), p.2614.

Krikke, H.., van Harten, a \& Schuur, P.., 1999. Business case Roteb: recovery strategies for monitors. Computers \& Industrial Engineering, 36(4), pp.739-757.

KTN, 2012. How to comply with UK healthcare regulations. Available at: http://www.healthktn.org/supportmap/how-to-comply-with-uk-healthcareregulations [Accessed August 8, 2014].

Kumar, M. \& Gregory, M., 2013. An exploration of risk management in global industrial investment. Risk Management, 15(4), pp.272-300.

Life Technologies, 2014. Product Stewardship. Available at: http://www.lifetechnologies.com/uk/en/home/about-us/productstewardship.html?CID=fl-productstewardship.html [Accessed August 22, 2014]. 
LifeScan, 2014. OneTouch ${ }^{\circledR}$ diabetic lancing devices. Available at: http://www.lifescan.co.uk/ourproducts/accessories/lancingdevice [Accessed August 28, 2014].

Linton, J., Klassen, R. \& Jayaraman, V., 2007. Sustainable supply chains: An introduction. Journal of Operations Management, 25(6), pp.1075-1082.

Loughborough University, 2014. Design optimisation of a needle-free drug delivery device.

Available

at:

http://www.lboro.ac.uk/microsites/research/lcbe/research/past-projects/needlefree.html [Accessed August 7, 2014].

Marchi, V. De, Maria, E. Di \& Micelli, S., 2013. Environmental Strategies, Upgrading and Competitive Advantage in Global Value Chains. Business Strategy and the Environment, 22(1), pp.62-72.

Marteel, A.E. et al., 2003. Green Chemistry and Enginnering: Drivers, Metrics, and Reduction to Practice. Annual Review of Environment and Resources, 28, pp.401428.

Martin, J., 1992. Conditions for Environmental Policy Success: An International Comparison. The Environmentalist, 12(1), pp.47-58.

Martin, M. \& Eklund, M., 2011. Improving the environmental performance of biofuels with industrial symbiosis. Biomass and Bioenergy, 35(5), pp.1747-1755.

Maxwell, D. \& van der Vorst, R., 2003. Developing sustainable products and services. Journal of Cleaner Production, 11(8), pp.883-895.

Medicina, 2014. Syringes. Available at: http://www.medicina.co.uk/syringes/ [Accessed August 30, 2014].

Medtech Europe, 2012. Creating Value in European Healthcare,

Medtech Europe, 2013. Medical Technology: Contributing to Europe's Health, Innovation and Economy,

MHRA, 2008. Medicines \& Medical Devices Regulation: What you need to know,

Moore, J.F., 2005. Business ecosystems and the view from the firm. Antitrust Bulletin, 51(1), pp.31-75.

Moore, K.E., Güngör, A. \& Gupta, S.M., 2001. Petri net approach to disassembly process planning for products with complex AND/OR precedence relationships. European Journal of Operational Research, 135(2), pp.428-449.

Morgan, G. \& Smircich, L., 1980. The Case for Qualitative Research. Academy of Management Review, 5(4), pp.491-500. 
Mueller, M., dos Santos, V.G. \& Seuring, S., 2009. The Contribution of Environmental and Social Standards Towards Ensuring Legitimacy in Supply Chain Governance. Journal of Business Ethics, 89(4), pp.509-523.

Murphy, J. \& Gouldson, A., 2000. Environmental policy and industrial innovation: integrating environment and economy through ecological modernisation. Geoforum, 31(1), pp.33-44.

Nagel, C. \& Meyer, P., 1999. Caught between ecology and economy: end-of-life aspects of environmentally conscious manufacturing. Computers \& Industrial Engineering 36, 36, pp.781-792.

Noor, K.B.M., 2008. Case Study: A Strategic Research Methodology. American Journal of Applied Science, 5(11), pp.1602-1604.

Orsato, R.J., 2006. Competitive Environmental Strategies: When Does It Pay to be Green? California Management Review, 48(2), pp.127-144.

PA Consulting, 2014. Exacsys, a PA Consulting Group company, publishes clinical evaluation results on how its technology can improve accuracy of Blood Glucose Monitoring. Available at: http://www.paconsulting.com/our-experience/exacsyspublishes-clinical-evaluation-results-in-the-journal-of-diabetes-science-andtechnology/ [Accessed August 21, 2014].

Platcheck, E.R. et al., 2008. Methodology of ecodesign for the development of more sustainable electro-electronic equipments. Journal of Cleaner Production, 16(1), pp.75-86.

Pol, V.G., 2010. Upcycling: converting waste plastics into paramagnetic, conducting, solid, pure carbon microspheres. Environmental science \& technology, 44(12), pp.4753-9.

Porter, M.E., 1998. CLUSTERS AND THE NEW ECONOMICS OF COMPETITION. Harbard Business Review, 76(6), pp.77-90.

Porter, M.E., 2007. Understanding Industry Structure. , (79208), pp.1-16.

Queen's University Belfast, 2014. Drug Delivery. Available at: http://www.qub.ac.uk/schools/SchoolofPharmacy/Research/PharmScienceandPract ice/DrugDelivery/ [Accessed August 7, 2014].

Rennings, K. et al., 2006. The influence of different characteristics of the EU environmental management and auditing scheme on technical environmental innovations and economic performance. Ecological Economics, 57(1), pp.45-59.

Roche, 2014. The Strip Free Accu-Chek® Mobile Blood Glucose Meter System. Available at: https://www.accu-chek.co.uk/gb/products/metersystems/mobile.html [Accessed August 22, 2014]. 
Romanowski, P., 2014. How Products are Made: Vol 3 - Syringe. Advameg, Inc. Available at: http://www.madehow.com/Volume-3/Syringe.html\#b [Accessed August 8, 2014].

Rondinelli, D. \& Vastag, G., 2000. Panacea, Common Sense, or Just a Label? The Value of ISO 14001 Environmental Management Systems. European Management Journal, 18(5), pp.499-510.

Science Museum, 2014. Hypodermic syringe. Available at: http://www.sciencemuseum.org.uk/broughttolife/techniques/hypodermicsyringe.as px [Accessed August 5, 2014].

SDU, 2014a. BMA moves away from fossil fuel companies. Available at: http://www.sduhealth.org.uk/news/289/bma-moves-away-from-fossil-fuelcompanies/ [Accessed August 21, 2014].

SDU, 2013. Carbon Footprint update for NHS in England 2012,

SDU, 2012. Greenhouse Gas Accounting Sector Guidance for Pharmaceutical Products and Medical Devices $G H G$,

SDU, 2014b. New $£ 800,000$ fund to help waste prevention projects. Available at: http://www.sduhealth.org.uk/news/283/new-800000-fund-to-help-wasteprevention-projects/ [Accessed August 21, 2014].

SDU, 2009. Saving Carbon, Improving Health: NHS CARBON REDUCTION STRATEGY FOR ENGLAND,

SDU, 2014c. Sustainable, Resilient, Healthy People \& Places: A Sustainable Development Strategy for the NHS, Public Health and Social Care System,

Sentec, 2014. Sentec: Product. Available at: http://www.sentecscientific.com/product [Accessed August 21, 2014].

Seuring, S. \& Gold, S., 2013. Sustainability management beyond corporate boundaries: from stakeholders to performance. Journal of Cleaner Production, 56, pp.1-6.

Seyfang, G., 2006. Sustainable consumption, the new economics and community currencies: Developing new institutions for environmental governance. Regional Studies, 40(7), pp.781-791.

Sharpsmart, 2010. Safer for the environment. Available at: http://sharpsmart.co.uk/ àpropos-de-nous/sécuritaire-pour-lenvironnement/environmental-safety [Accessed August 22, 2014].

Shi, Y. \& Gregory, M., 1998. International manufacturing networks - to develop global competitive capabilities.

SITA UK, 2013. Welcome. Available at: http://www.sita.co.uk [Accessed August 8, 2014]. 
Skinner, C.W., 1964. Management of International Production. Harvard Business Review, 42(5), pp.125-136.

Skinner, C.W., 1969. Manufacturing-Missing Link in Corporate Strategy. Harvard Business Review, 47(3), pp.136-145.

Smith, S. \& Yen, C.-C., 2010. Green product design through product modularization using atomic theory. Robotics and Computer-Integrated Manufacturing, 26(6), pp.790-798.

Southerton, D., Chappells, H. \& Van Vliet, B., 2004. Sustainable Consumption: The Implication of Changing Infrastructure of Provision, Edward Elgar Publishing Limited.

Srai, J.S., Alinaghian, L.S. \& Kirkwood, D. a., 2013. Understanding sustainable supply network capabilities of multinationals: A capability maturity model approach. Proceedings of the Institution of Mechanical Engineers, Part B: Journal of Engineering Manufacture, 227(4), pp.595-615.

Srai, J.S. \& Christodoulou, P., 2014. Capturing value from global networks: strategic approaches to configuring international production, supply and service operations, Cambridge: University of Cambridge Institute for Manufacturing.

SRCL, 2011. We are the UK's leading healthcare services company. Available at: http://www.srcl.com [Accessed August 8, 2014].

Srivastava, S.K., 2007. Green supply-chain management: A state-of-the-art literature review. International Journal of Management Reviews, 9(1), pp.53-80.

Star Syringe, 2014. Licensing: The most comprehensive, global, auto-disable syringe manufacturing base. Available at: http://www.starsyringe.com/licensing.htm [Accessed August 29, 2014].

Stivers, R.L., 1976. The Sustainable Society: Ethics and Economic Growth First., California: Westminster John Knox Press.

Sturgeon, T.J., 2001. How Do We Define Value Chains and Production Networks?*. IDS Bulletin, 32(3), pp.9-18.

TDAP, 2012. An Overview: Surgical \& Medical Instruments of Pakistan,

Tessarolo, F., Caola, I. \& Nollo, G., 2011. Critical Issues in Reprocessing Single-Use Medical Devices for Interventional Cardiology, Italy.

TFDI, 2013. UK Health Care and ICT: Current market intelligence report December 2013 ,

The Council of the European Union, 2010. Council Directive 2010/32/EU: implementing the Framework Agreement on prevention from sharps injuries in the 
hospital and healthcare sector concluded by HOSPEEM and EPSU. Official Journal of the European Union, 154(10), pp.66-72.

The Royal Academy of Engineering, 2007. Creating systems that work: Principles of engineering systems for the 21st century,

The Royal Academy of Engineering, 2012. Industrial Systems: capturing value through manufacturing, London.

The University of Edinburgh, 2006. Decontamination of Surgical Instruments with MIDAS. Available at: http://www.universitytechnology.com/opportunity/314/decontamination-of-surgical-instruments-withmidas [Accessed August 20, 2014].

Tridech, S. \& Cheng, K., 2010. An investigation on the framework for EREE-based low carbon manufacturing. 5th International Conference on Responsive Manufacturing - Green Manufacturing (ICRM 2010), pp.257-267.

Tsoulfas, G.T. \& Pappis, C.P., 2006. Environmental principles applicable to supply chains design and operation. Journal of Cleaner Production, 14(18), pp.15931602.

UK Trade \& Investment, 2013. Medica 2013 Düsseldorf.

University of Glasgow, 2014. Diabetes, Renal, Endocrine \& Metabolic Disease (DREAM). Available at: http://www.gla.ac.uk/researchinstitutes/icams/research/diabetesrenalendocrineand metabolicmedicine/ [Accessed August 7, 2014].

University of Kings College London, 2014. Diabetes Research Group. Available at: http://www.kcl.ac.uk/medicine/research/divisions/dns/research/diabetes/index.aspx [Accessed August 7, 2014].

University of Leeds, 2014. Division of Cardiovascular and Diabetes. Available at: http://medhealth.leeds.ac.uk/info/521/division_of_cardiovascular_and_diabetes// [Accessed August 7, 2014].

University of Southampton, 2014. Research Group: Molecular and Cellular Biosciences. http://www.southampton.ac.uk/biosci/research/groups/molecular_and_cellular.pag e [Accessed August 7, 2014].

University of Strathclyde Glasgow, 2014. Ultra fast PCR technology for medical and biosecurity diagnostics.

Unversity of Dundee, 2014. Dundee Diabetes Research Centre. Available at: http://medicine.dundee.ac.uk/dundee-diabetes-research-centre [Accessed August 7, 2014]. 
USDA NIFA, 2014. Real Time PCR - Some Basic Principles. Plant and Soil Sciences eLibrary.

Vachon, S. \& Klassen, R.D., 2006. Extending green practices across the supply chain: The impact of upstream and downstream integration. International Journal of Operations \& Production Management, 26(7), pp.795-821.

Wacker, J., 1998. A definition of theory: research guidelines for different theorybuilding research methods in operations management. Journal of Operations Management, 16(4), pp.361-385.

Wang, G. \& Côté, R., 2011. Integrating eco-efficiency and eco-effectiveness into the design of sustainable industrial systems in China. International Journal of Sustainable Development \& World Ecology, 18(1), pp.65-77.

WCED, 1987. Our Common Future 1st ed., Oxford: Oxford University Press.

Whitney, D.E., Baldwin, C.Y. \& Magee, C.L., 2011. How Firm Strategies Influence the Architecture of Transaction Networks How Firm Strategies Influence the Architecture of Transaction Networks. Industrial and Corporate Change.

Wirral NHS, 2008. Single Use Medical Devices Policy: Infection Control Policy No 6 Version 2,

Yang, S. \& Rothman, R.E., 2004. Review PCR-based diagnostics for infectious diseases: uses, limitations, and future applications in acute-care settings. The LANCET Infectious Diseases, pp.337-348.

Yang, T. \& Percival, R. V, 2009. The Emergence of Global Environmental Law. Ecology Law Quarterly, 36(3), pp.615-664.

Yin, R.K., 1994. Case Study Research: Design and Methods Second., London: Sage Publications Ltd.

Yuan, Z., Bi, J. \& Moriguichi, Y., 2006. The Circular Economy: A New Development Strategy in China. Journal of Industrial Ecology, 10, pp.4-8. 